Notre Dame Law School

NDLScholarship

Journal Articles

Publications

2014

\title{
Second Thoughts About the First Amendment
}

Randy J. Kozel

Notre Dame Law School, rkozel@nd.edu

Follow this and additional works at: https://scholarship.law.nd.edu/law_faculty_scholarship

Part of the Constitutional Law Commons, Courts Commons, and the First Amendment $\underline{\text { Commons }}$

\section{Recommended Citation}

Randy J. Kozel, Second Thoughts About the First Amendment, Notre Dame Legal Studies Paper No. 1434 (August 5, 2014).

Available at: https://scholarship.law.nd.edu/law_faculty_scholarship/1117

This Article is brought to you for free and open access by the Publications at NDLScholarship. It has been accepted for inclusion in Journal Articles by an authorized administrator of NDLScholarship. For more information, please contact lawdr@nd.edu. 


\title{
THE SCOPE OF PRECEDENT
}

\author{
Randy J. Kozel*
}

The scope of Supreme Court precedent is capacious. Justices of the Court commonly defer to sweeping rationales and elaborate doctrinal frameworks articulated by their predecessors. This practice infuses judicial precedent with the prescriptive power of enacted constitutional and statutory text. The lower federal courts follow suit, regularly abiding by the Supreme Court's broad pronouncements. These phenomena cannot be explained by-and, indeed, oftentimes subvert-the classic distinction between binding holdings and dispensable dicta.

This Article connects the scope of precedent with recurring and foundational debates about the proper ends of judicial interpretation. A precedent's forward-looking effect should not depend on the superficial categories of holding and dictum. Instead, it should reflect deeper normative commitments that define the nature of adjudication within American legal culture.

The account that emerges is one in which the scope of precedent is inextricably linked to interpretive theory and constitutional understandings. Divergent methods of interpretation, from originalism to common law constitutionalism and beyond, carry distinctive implications for describing a precedent's constraining effect. So, too, do various methods of interpretation in the statutory and common law contexts. Ultimately, what should determine the scope of precedent is the set of premises-regarding the judicial role, the separation of powers, and the relevance of history, morality, and policy-that informs a judge's methodological choices.

\section{Table of Contents}

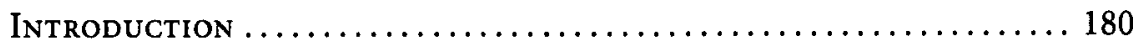

I. Precedent in Practice ........................... 185

A. From Persuasion to Deference .................. 185

B. Starting Points: The Holding-Dicta Distinction .......... 187

C. Precedential Breadth at the Supreme Court ............ 190

1. Unmistakable Dicta ........................ 191

2. Doctrinal Frameworks .................... 193

* Associate Professor of Law, Notre Dame Law School. For helpful comments and conversations, thanks to Amy Barrett, Charles Barzun, Will Baude, Aaron Bruhl, Josh Chafetz, Barry Cushman, Marc DeGirolami, Erin Delaney, Richard Ekins, Richard Garnett, Bert Huang, Bruce Huber, Leslie Kendrick, Jeff King, Kurt Lash, Sophia Lee, George Letsas, Jason Mazzone, Michael McConnell, John McGinnis, Eva Nanopoulos, Caleb Nelson, Chad Oldfather, Jeffrey Pojanowski, Zachary Price, John Robinson, Jay Tidmarsh, Eugene Volokh, Kevin Walsh, Gregoire Webber, Paul Yowell, and participants at the International Perspectives on Public Law Conference in London, England; the Federalist Society Junior Scholars Colloquium; and faculty colloquia at Northwestern University School of Law and Notre Dame Law School. 
3. Codifying Statements ...................... 196

4. Supporting Rationales....................... 197

D. Precedential Breadth in the Lower Federal Courts .......... 198

II. Clarifying the Inclusive Paradigm of Precedent ........ 199

A. Inclusive Versus Infinite ........................ 200

B. Dichotomy Versus Continuum ...................201

C. Superficial Labels Versus Theoretical Drivers .............. 202

III. Reconceptualizing Precedential Scope .................202

A. Distinguishing the Horizontal and Vertical Spheres ........202

1. Vertical Constraint ........................... 203

2. Horizontal Constraint ..........................204

B. The Costs and Benefits of Constraint ................204

1. Potential Benefits of Constraint ..................204

2. Potential Costs of Constraint .................... 207

3. Differential Approaches to Scope ...............211

C. Precedential Scope and Interpretive Foundations .........212

1. Common Law Constitutionalism ................ 212

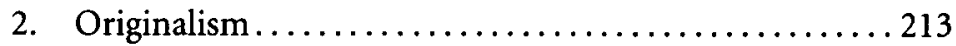

3. Pragmatism............................... 215

4. Conventionalism .........................217

5. Other Normative Commitments and Constitutional Understandings ........................... 218

6. Summary: Precedential Scope and the Supreme Court's Role......................................221

D. The Scope of Statutory and Common Law Precedents....... 222

1. Statutory Precedents ........................ 222

2. Common Law Precedents .................... 223

IV. Reforming Precedential Scope..................... 223

A. Analytical Transparency ..........................224

B. Jurisprudential Consistency .......................225

V. Comparative Institutional Considerations............227

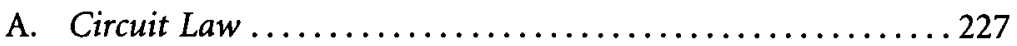

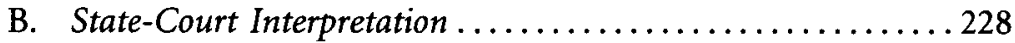

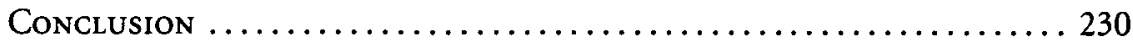

\section{INTRODUCTION}

Whether to overrule a dubious precedent is one of the most significant and complex questions that judges confront.' The topic has, quite properly,

1. See, e.g., Randy E. Barnett, Trumping Precedent with Original Meaning: Not as Radical as It Sounds, 22 Const. Comment. 257, 261 (2005) ("How and when precedent should be rejected remains one of the great unresolved controversies of jurisprudence."). 
received considerable attention in case law, ${ }^{2}$ scholarly commentary, ${ }^{3}$ and political discourse. ${ }^{4}$

But there is a complementary question of equal significance-and equal complexity-whose nuances have received less attention in recent scholarship. ${ }^{5}$ That question is whether a given precedent applies to a newly arising dispute. ${ }^{6}$ If the answer is yes, the prospect of overruling becomes relevant. If the answer is no, it is unnecessary to assess the costs and benefits of deviating from settled law. A precedent's scope of applicability thus presents a matter of threshold importance. ${ }^{7}$

Issues of precedential scope are ever present and often controversial. Should a decision dealing with the use of affirmative action at the University of Michigan apply to the University of Texas notwithstanding differences in the schools' demographic conditions? ${ }^{8}$ Should a decision protecting a corporation's right to participate in political referenda apply to candidate elections? ${ }^{9}$ To the rights of labor unions? ${ }^{10}$ Should a decision striking down a

2. For recent examples at the U.S. Supreme Court, see Citizens United v. FEC, $130 \mathrm{~S}$. Ct. 876, 911-12 (2010); Arizona v. Gant, 556 U.S. 332, 348 (2009); and Montejo v. Louisiana, 556 U.S. 778,797 (2009).

3. See, e.g., John O. McGinnis \& Michael B. Rappaport, Reconciling Originalism and Precedent, 103 Nw. U. L. Rev. 803 (2009); David L. Shapiro, The Role of Precedent in Constitutional Adjudication: An Introspection, 86 Tex. L. Rev. 929 (2008); Kurt T. Lash, Originalism, Popular Sovereignty, and Reverse Stare Decisis, 93 VA. L. Rev. 1437 (2007); David A. Strauss, Common Law Constitutional Interpretation, 63 U. CHI. L. Rev. 877 (1996).

4. See, e.g., Confirmation Hearing on the Nomination of John G. Roberts, Jr. to Be Chief Justice of the United States Before the S. Comm. on the Judiciary, 109th Cong. 144 (2005) ("An overruling of a prior precedent is a jolt to the legal system. It is inconsistent with principles of stability and yet ... the principles of stare decisis recognize that there are situations when that's a price that has to be paid.").

5. See Michael Abramowicz \& Maxwell Stearns, Defining Dicta, 57 Stan. L. Rev. 953, 958 n.11 (2005) (noting the relative paucity of scholarly attention to precedential scope in recent years). Among the most notable exceptions are Professors Abramowicz and Stearns's article and Professor Duxbury's insightful book on precedent and legal reasoning. See generally Neil Duxbury, The Nature and Authority of Precedent (2008).

6. See, e.g., Daniel A. Farber, The Rule of Law and the Law of Precedents, 90 MinN. L. Rev. 1173, 1199 (2006) ("It is one thing to say that a precedent should be followed. It is another to say precisely what it means to follow precedent.").

7. See Abramowicz \& Stearns, supra note 5, at 957 ("[B]efore a court can decide whether to apply the doctrine of stare decisis to a given case, it must first determine just what that case purports to establish."); Earl Maltz, The Nature of Precedent, 66 N.C. L. Rev. 367, 372 (1988) (isolating the question of precedential scope for independent analysis).

8. Compare Grutter v. Bollinger, 539 U.S. 306 (2003), with Fisher v. Univ. of Tex. at Austin, 631 F.3d 213 (5th Cir. 2011), vacated and remanded, 133 S. Ct. 2411 (2013).

9. Compare Austin v. Mich. Chamber of Commerce, 494 U.S. 652 (1990), with Citizens United v. FEC, 130 S. Ct. 876 (2010).

10. See FEC Advisory Op. 2010-11, at 3 n.3 (Commonsense Ten) (2010) (noting that "Citizens United did not directly address whether labor organizations" enjoy the same constitutional protections as corporations in advocating for the election or defeat of political candidates). 
federal statute that rejects same-sex marriage apply to comparable statutes enacted by the states? ${ }^{11}$

These questions aim to define the scope of precedent. The standard account of scope begins with the distinction between binding holdings and nonessential dicta: judicial holdings are entitled to deference from future courts, while everything else is dispensable. ${ }^{12}$ Indeed, the Supreme Court recently reaffirmed that dicta from its prior opinions may be freely disregarded. Simply because the Court has "once written dicta calling a tomato a vegetable" does not mean that subsequent judges are "bound to deny that it is fruit forever after."13

Nevertheless, the Court's practice often departs from these general principles. The inconsistency runs deeper than the well-chronicled difficulty of sorting dicta from holdings in particular cases. ${ }^{14}$ To be sure, the Court goes to great lengths to characterize certain statements as mere dicta that can be jettisoned without reservation. But in many other cases, the Court defers to elements of its prior opinions that extend far beyond the narrow application of a legal rule to a discrete set of facts. ${ }^{15}$ Those elements include doctrinal frameworks, elaborate judicial instructions, and broadly articulated rationales. ${ }^{16}$ The phenomenon is even more pronounced in the lower federal courts, many of which unabashedly defer to Supreme Court dicta. Recent scholarship underscores the point by highlighting the porous nature of the line between holdings and dicta in practice. ${ }^{17}$ The result is the prevalence of

11. See United States v. Windsor, 133 S. Ct. 2675 (2013); id. at 2696 (Roberts, C.J., dissenting) ("The Court does not have before it, and the logic of its opinion does not decide, the distinct question whether the States ... may continue to utilize the traditional definition of marriage.").

12. See, e.g., Black's Law Dictionary $1177^{\prime}$ (9th ed. 2009) (describing dicta as "not precedential").

13. Kirtsaeng v. John Wiley \& Sons, 133 S. Ct. 1351, 1368 (2013); see also, e.g., Jama v. Immigration \& Customs Enforcement, 543 U.S. 335, 351 n.12 (2005) ("Dictum settles nothing, even in the court that utters it.").

14. E.g., Michael C. Dorf, Dicta and Article III, 142 U. PA. L. Rev. 1997, 2005 (1994) (arguing that "[a]s currently understood, the distinction [between holding and dicta] is almost entirely malleable"); $c f$. Richard H. Fallon, Jr., Implementing the Constitution, 111 Harv. L. REV, 54, 124 (1997) ("It is notorious, even to the Justices themselves, that a broad ambit frequently exists for reasonable disagreement about how precedents are best interpreted and tests best applied."); Henry Paul Monaghan, Stare Decisis and Constitutional Adjudication, 88 Colum. L. Rev. 723, 743 (1988) ("Because a coherent rationale for the intermittent invocation of stare decisis has not been forthcoming, the impression is created that the doctrine is invoked only as a mask hiding other considerations.").

15. See infra Sections I.B-C.

16. See Fallon, supra note 14 , at 56 ("Among the most important functions of the Supreme Court are to craft and apply constitutional doctrine-a term that [includes] not only the holdings of cases, but also the analytical frameworks and tests that the Court's cases establish." (footnote omitted)).

17. David Klein \& Neal Devins, Dicta, Schmicta: Theory Versus Practice in Lower Court Decision Making, 54 WM. \& MARY L. Rev. 2021, 2026 (2013) (arguing that "[l]ower courts often mention the distinction between holding and dictum but hardly ever invoke it in consequential ways"); Judith M. Stinson, Why Dicta Becomes Holding and Why It Matters, 76 Brook. 
an inclusive paradigm of precedent in which binding effect attaches to a vast array of judicial propositions.

The inclusive definition of precedent is on display when the Supreme Court defers to a wide-ranging doctrinal framework in applying the Bill of Rights against the states. ${ }^{18}$ It is on display when the Court's detailed warnings for criminal suspects receive deference in subsequent adjudication. ${ }^{19}$ And it is on display when a federal appellate judge suggests that Supreme Court dicta foreclose her independent interpretation of the Establishment Clause. ${ }^{20}$

In some situations, broad interpretations of precedent are arguably consistent with the black-letter definition of judicial holdings as propositions that are "necessary" to a case's result. ${ }^{21}$ But that fact does not justify the inclusive paradigm of precedent. It simply demonstrates the ambiguity that resides within the terms "holding" and "dicta," terms that create far greater potential for mischief than illumination. The dangers are exacerbated when, as is often the case, the terms are deployed in isolation from the underlying principles that give them meaning. The proper question is not whether a particular judicial statement is better described as holding or dictum. Rather, it is why holdings should be entitled to deference-and why dicta should not-in the first place.

This question cannot be answered in the abstract. It is impossible to provide a complete account of precedential scope without adopting, either overtly or implicitly, a specific vision of the function of precedent and the nature of the judicial role. Such a vision will be informed by matters of interpretive methodology and constitutional theory. For jurists and commentators who view the Constitution as imposing strict limits on judicial lawmaking, the inclusive paradigm of precedent creates problems by infusing much of what judges say with constraining force. The same is true for those who view the Constitution's original meaning as paramount to judicial precedent in all but the narrowest circumstances. But for others, the virtues of guiding lower courts and respecting prior judicial pronouncements serve to justify the inclusive paradigm. ${ }^{22}$

Perspectives on the scope of precedent are thus intertwined with deeper principles of interpretation and adjudication. A judicial opinion has no intrinsic meaning. Its effect depends on the interpretive lens through which it is viewed. Think of it like a quantum theory of precedent: the interpretive sympathies of the particular observer end up determining what is binding

L. Rev. 219, 221 (2010) (arguing that "too often lawyers argue for, and judges treat, extraneous statements made in a prior case-that is, dicta-as holding").

18. See McDonald v. City of Chicago, 130 S. Ct. 3020 (2010).

19. See Miranda v. Arizona, 384 U.S. 436 (1966); infra Section I.C.3.

20. See Myers v. Loudoun Cnty. Pub. Sch., 418 F.3d 395, 410-11 (4th Cir. 2005) (Motz, J., concurring in the judgment).

21. Seminole Tribe of Fla. v. Florida, 517 U.S. 44, 67 (1996).

22. See infra Section III.C. 
and what is not. ${ }^{23} \mathrm{~A}$ court cannot assess whether a flawed decision should be overruled without consulting interpretive touchstones to determine how problematic it would be to leave the offending decision on the books. ${ }^{24}$ Similarly, a court cannot fully evaluate whether a decision applies to a new dispute without asking questions such as whether the Supreme Court should play an active role as the federal judiciary's manager; whether the lower courts are bound to act as the Supreme Court's faithful agents rather than charting their own course; and whether the Constitution places meaningful limits on the power of today's judges to constrain those of tomorrow.

Many of these questions draw on the unique role and structure of the federal judiciary. This Article accordingly focuses on the treatment of Supreme Court precedents by subsequent federal courts, including the Supreme Court itself. Properly analyzing the implications of precedent requires attention to specific institutional features that are not shared by all courts. To take just one example, the argument for interpreting Supreme Court decisions broadly may be stronger with respect to federal appellate courts than it is with respect to state supreme courts, because the constraint of state courts raises unique issues for the federal-state balance. ${ }^{25}$ More generally, the intractable nature of debates over precedential scope arises in part from their formulation in abstract terms. Examining the ramifications of constraint in light of the specific characteristics of particular courts makes the puzzles of precedent at once more manageable and more responsive to context.

This Article proceeds in five stages. Part I examines the treatment of precedential scope as a matter of contemporary federal practice. It explains how the prevailing definition of precedent is capacious and inclusive, imbuing a wide range of judicial propositions with binding effect. Part II adds precision by exploring the inclusive paradigm's assumptions and boundaries.

Having provided a descriptive and analytical account of the scope of precedent, the Article turns in Part III to evaluating the inclusive paradigm and comparing it with a more restrictive approach. That project requires engaging with fundamental interpretive choices and constitutional understandings, both of which determine how the costs and benefits of precedential constraint should be perceived and weighed against one another.

Drawing on the relationship between precedential scope and interpretive theory, Part IV offers two proposals for doctrinal reform. The initial

23. Cf. Laurence H. Tribe, The Curvature of Constitutional Space: What Lawyers Can Learn from Modern Physics, 103 HARv. L. Rev. 1, 19 (1989) ("The deeper philosophical insight underlying the Heisenberg Principle is ... that the observer is never really separate from the system being studied, even though the contrary presumption might occasionally be a useful abstraction.").

24. Lash, supra note 3, at 1439 (noting the importance of "a normative theory that weighs the costs of interpretive error against the benefits of following precedent"). See generally Randy J. Kozel, Settled Versus Right: Constitutional Method and the Path of Precedent, 91 TEx. L. Rev. 1843 (2013).

25. See infra Section V.B. 
goal is enhanced analytical transparency regarding the scope of precedenta development that becomes plausible once the role of interpretive theory and constitutional understandings comes into focus. The second, more ambitious proposal seeks not just transparency but analytical consistency, combined with recognition of the serious challenges posed by individual judges' interpretive vacillation and by the Supreme Court's institutional reluctance to commit itself to any unified method of legal interpretation. While the Court's interpretive pluralism is a formidable obstacle to developing an effective doctrine of stare decisis, the pursuit of transparency and consistency is a promising, although imperfect and incomplete, means of improving the existing jurisprudence.

Finally, Part V looks beyond the Supreme Court to explain how debates over the scope of precedent depend on the unique structural characteristics of the courts that issue decisions and the courts that apply them.

\section{Precedent in Practice}

It is a truth universally acknowledged that a judge who is asked to resolve a thorny dispute must be presented with competing arguments from precedent. ${ }^{26}$ One party will claim that the body of relevant case law demands, or at least strongly suggests, a certain outcome. The opposing party will contend that the proper inference from precedent is actually quite the contrary. And so the meaning of precedent will be placed before the judge for resolution. ${ }^{27}$

\section{A. From Persuasion to Deference}

The role of precedent depends on two concepts that are interrelated but analytically distinct. The first is precedential scope, which determines whether a prior judicial statement applies to the dispute presently under consideration. The second is precedential strength, which determines how much deference is owed to prior statements that are, in fact, applicable. This Article's primary concern is the threshold matter of scope. Before turning to that issue, however, I offer a brief introduction to the nature and import of precedential strength.

A judge is always free to consider a prior statement for its persuasive value, even if she regards the statement as dispensable dicta. Looking to a proposition for its persuasive force is a means of vetting the merits of a legal argument. A judge who considers a proposition's persuasive value does not thereby defer to its author. Nor does she endorse a presumption in favor of

26. Cf. Jane Austen, Pride and Prejudice 1 (R.W. Chapman ed., Oxford Univ. Press 1923) (1813).

27. See, e.g., Kitchen v. Herbert, 961 F. Supp. 2d 1181, 1193 (D. Utah 2013) ("Both parties argue that the reasoning in Windsor requires judgment in their favor."); see also Frederick Schauer, Precedent, 39 STAN. L. Rev. 571, 579 (1987) ("The task of a theory of precedent is to explain, in a world in which a single event may fit into many different categories, how and why some assimilations are plausible and others are not."). 
the status quo. She simply seeks a proper understanding of the relevant arguments before reaching her own independent conclusion. ${ }^{28} \mathrm{~A}$ judicial proposition that is treated as persuasive carries no force beyond that which might accrue to an amicus curiae brief or a scholarly treatise. ${ }^{29}$ If the proposition is correct, it will carry the day. If it is incorrect, it will fall by the wayside.

A subsequent judge defers to a prior decision only when she contemplates the possibility of abiding by the decision despite the fact that its reasoning does not persuade her. The potential explanations for deference are manifold. It may be that the judge has some doubt-or, perhaps, humilityabout her ability to reach the correct result on the merits, leading her to subordinate her best understanding to the conclusions of prior tribunals. ${ }^{30}$ Alternatively, the judge may be quite confident that the applicable precedent is incorrect. Yet she may still choose to abide by the precedent based on her belief that overruling it would create substantial transition costs and upset settled expectations. ${ }^{31}$ Whatever her motivation, the judge defers by treating a precedent as though it draws authority from sources other than its logical appeal.

Deference is not an all-or-nothing proposition. The strength of deference may depend on the type of case, as with the Supreme Court's practice of giving extra insulation to (most) statutory precedents. ${ }^{32}$ The strength of deference may also vary based on a court's hierarchical rank; the Supreme Court's decisions are absolutely binding on inferior federal courts but susceptible to overruling by the Supreme Court itself. ${ }^{33}$ In all events, deference to precedent means that future judges might-not necessarily will, but might-abide by a prior decision despite disagreeing with its rationale. The corollary is that a precedent can be "binding" in the sense of requiring presumptive deference even if countervailing factors may trigger the precedent's overruling.

Through this understanding of persuasion and deference, the relationship between precedential strength and precedential scope becomes clear. If

28. Kasten v. Saint-Gobain Performance Plastics Corp., 131 S. Ct. 1325, 1340 n.6 (2011) (Scalia, J., dissenting) ("If one has been persuaded by another, so that one's judgment accords with the other's, there is no room for deferral-only agreement.").

29. See Frederick Schauer, Authority and Authorities, 94 VA. L. REv. 1931, 1943 (2008) ("[I]f authority is genuinely at work, then the agent who accepts the authoritativeness of a directive need not be persuaded by the substantive reasons that might support the same conclusion.").

30. E.g., Laurence H. Tribe, The Invisible Constitution 208 (Geoffrey R. Stone ed., 2008) (connecting deference to precedent with judicial humility).

31. See Larry Alexander, Constrained by Precedent, 63 S. CAL. L. Rev. 1, 13 (1989) ("If the decision in the precedent case has generated expectations of similar future decisions on which people have relied ... and a decision that the [current] court would otherwise find correct would dash those expectations, then the opposite decision may in fact be the correct one.").

32. E.g., Patterson v. McLean Credit Union, 491 U.S. 164, 172-73 (1989) ("Considerations of stare decisis have special force in the area of statutory interpretation . : . .").

33. See infra Section III.A.1. 
a given precedent is broad enough to cover a newly arising dispute, it will exert constraining force that exceeds its persuasiveness. Unlike a merely persuasive proposition, a binding proposition requires a judge to show something more than disagreement in order to justify departing from the past. It is the definition of a precedent's scope of applicability that makes the strength of deference relevant to the analysis. The corollary is that, when judges interpret precedent broadly, the strength of deference becomes crucial to determining what is settled and what is open for debate.

\section{B. Starting Points: The Holding-Dicta Distinction}

The classic account of precedential scope revolves around a stark dichotomy. Judicial holdings receive deference in future cases. Dicta, by contrast, have no constraining force and are relevant only to the extent that their reasoning is persuasive. ${ }^{34}$ Chief Justice Marshall made this point nearly two centuries ago in Cohens $v$. Virginia, noting that, while expressions that "go beyond the case ... may be respected," they do not control "in a subsequent suit when the very point is presented for decision." 35

The same principle is evident in the Supreme Court's modern case law. ${ }^{36}$ The Court's decisions regularly confirm the nonbinding nature of dicta. ${ }^{37}$ By way of illustration, consider the Court's recent echo of Cohens in noting that "we are not necessarily bound by dicta should more complete argument demonstrate that the dicta is not correct." 38 Consider, too, Justice Scalia's assertion that, even if dicta are "repeated" over time, they are "not owed stare decisis weight," 39 as well as his statement that dicta are "binding upon neither" the Supreme Court nor the inferior courts. ${ }^{40}$ Whenever a

34. For an account of the various ways in which authorities can be persuasive, see Lawrence B. Solum, How NFIB v. Sebelius Affects the Constitutional Gestalt, 91 WASH. U. L. REv. 1 (2013). "Persuasive authority has four distinct but related components: (1) persuasion by reasons, (2) persuasion by epistemic authority, (3) persuasion by predictive authority, and (4) persuasion by legitimating authority." Id. at 38 .

35. 19 U.S. (6 Wheat.) 264,339 (1821).

36. See, e.g., Ark. Game \& Fish Comm'n v. United States, 133 S. Ct. 511, 520 (2012) (calling the Cohens language a "sage observation"); Cent. Va. Cmty. Coll. v. Katz, 546 U.S. 356, 363 (2006) ("For the reasons stated by Chief Justice Marshall in [Cohens], we are not bound to follow our dicta in a prior case in which the point now at issue was not fully debated.").

37. See, e.g., Cent. Green Co. v. United States, 531 U.S. 425, 431 (2001) (noting that "dicta 'may be followed if sufficiently persuasive' but are not binding" (quoting Humphrey's Ex'r v. United States, 295 U.S. 602, 627 (1935))); U.S. Bancorp Mortg. Co. v. Bonner Mall P'ship, 513 U.S. 18, 24 (1994) (noting the Supreme Court's “customary refusal to be bound by dicta").

38. Kirtsaeng v. John Wiley \& Sons, 133 S. Ct. 1351, 1368 (2013).

39. Gonzales v. United States, 553 U.S. 242, 256 (2008) (Scalia, J., concurring in the judgment).

40. CIGNA Corp. v. Amara, 131 S. Ct. 1866, 1884 (2011) (Scalia, J., concurring in the judgment); see also, e.g., Thompson v. N. Am. Stainless, LP, 131 S. Ct. 863, 869 (2011) ("We 
court treats a proposition as undeserving of deference because it was beyond "the narrow point decided," the holding-dicta distinction is at work. ${ }^{41}$

The Supreme Court has described the holding of a case as including its "final disposition" in addition to "the preceding determinations "necessary to that result." "42 Holdings must also be grounded in "the adjudicated facts"; 43 hypothetical statements are the stuff of dicta. On this view, precedential effect attaches to the application of a targeted legal rule to a discrete set of facts that were actually presented in the underlying dispute. It is true, of course, that Supreme Court opinions are full of logical arguments and prescriptions for the future. As Justice Stevens has noted, "[v]irtually every one of the Court's opinions announcing a new application of a constitutional principle contains some explanatory language that is intended to provide guidance to lawyers and judges in future cases." 44 Even so, it is important to recognize that the distinction between holdings and dicta would deny deference to unnecessary and hypothetical statements even when they were clearly intended to guide future courts. ${ }^{45}$ Such statements may or may not be convincing on the merits, but in no event would they warrant deference beyond their persuasive force.

The enduring salience of the holding-dicta distinction is visible whenever the Supreme Court marginalizes its past expressions by depicting them as peripheral or overbroad. A useful illustration is the Court's recent decision in United States v. Alvarez. ${ }^{46}$ In Alvarez, which struck down a federal statute that prohibited fabricated claims of military commendation, a plurality of justices determined that false statements possess some value in the eyes of the First Amendment. ${ }^{47}$ Before reaching that conclusion, the plurality had to confront language in the Court's prior opinions supporting the contrary view that false claims possess no intrinsic value. ${ }^{48}$ The plurality downplayed

now find that this dictum was ill-considered, and we decline to follow it."); District of Columbia v. Heller, 554 U.S. 570,625 n.25 (2008) ("It is inconceivable that we would rest our interpretation of the basic meaning of any guarantee of the Bill of Rights upon such a footnoted dictum in a case where the point was not at issue and was not argued.").

41. Humphrey's Ex'r v. United States, 295 U.S. 602, 626 (1935).

42. Tyler v. Cain, 533 U.S. 656, 663 n.4 (2001) (quoting Seminole Tribe of Fla. v. Florida, 517 U.S. 44, 67 (1996)) (emphasis in Tyler); cf. Black's Law Dictionary 1177 (9th ed. 2009) (defining "obiter dictum" to mean a judicial comment "that is unnecessary to the decision in the case and therefore not precedential (although it may be considered persuasive)").

43. Evan H. Caminker, Precedent and Prediction: The Forward-Looking Aspects of Inferior Court Decisionmaking, 73 TEx. L. REv. 1, 14 (1994).

44. See Carey v. Musladin, 549 U.S. 70, 79 (2006) (Stevens, J., concurring in the judgment).

45. See Schauer, supra note 27 , at 580 (noting that, "[i]n classical legal theory, articulated characterizations are often considered mere dicta").

46. 132 S. Ct. 2537 (2012) (plurality opinion).

47. See Alvarez, 132 S. Ct. at 2546-47 (plurality opinion).

48. See, e.g., Hustler Magazine, Inc. v. Falwell, 485 U.S. 46, 52 (1988) ("False statements of fact are particularly valueless; they interfere with the truth-seeking function of the marketplace of ideas, and they cause damage to an individual's reputation that cannot easily be repaired by counterspeech, however persuasive or effective."). 
the problematic language as consisting of "isolated statements" uttered in a different context. ${ }^{49}$ According to the plurality, all the opinions that had described false statements as valueless involved "defamation, fraud, or some other legally cognizable harm ... such as an invasion of privacy or the costs of vexatious litigation." ${ }^{0}$ There was no justification for deference outside of those situations, regardless of whether the Court's previous language suggested a general principle that false speech is valueless. By drawing a rigid line between fact-intensive rulings and nonbinding judicial exposition, the Alvarez plurality highlighted the importance of sorting holdings from dicta.

To the same effect is United States $v$. Stevens, a case dealing with a criminal statute aimed at depictions of animal cruelty. ${ }^{51}$ In defending the statute's constitutionality, the U.S. Solicitor General pressed an argument grounded in cost-benefit analysis: because depictions of animal cruelty have meager social value but impose significant social harm, they should be treated as a categorical exception to First Amendment protection. ${ }^{52}$ The Solicitor General's argument drew on previous cases in which the Court had described this type of cost-benefit analysis as relevant to constitutional protection. ${ }^{53}$ But Stevens dismissed the Court's prior acceptance of cost-benefit analysis as merely "descriptive." 54 According to Stevens, the Court's language linking First Amendment coverage to cost-benefit analysis was window dressing. The language did not "set forth a test that may be applied as a general matter." ${ }^{55}$ In this way, the Court framed its new approach to identifying categorical exceptions (which is expressly tied to historical practice rather than to the weighing of costs and benefits) as familiar despite the fact that it clashed with the language of decisions that preceded it. ${ }^{56}$

Similar dynamics are evident in the Supreme Court's most famous application of stare decisis, Planned Parenthood of Southeastern Pennsylvania v. Casey. ${ }^{57}$ When the Court first addressed the constitutional implications of abortion in Roe v. Wade, it ventured far beyond the facts at hand to articulate an elaborate framework for evaluating abortion regulations based on the trimester of pregnancy. ${ }^{58}$ That framework was not an essential statement or

49. Alvarez, 132 S. Ct. 2544 (plurality opinion).

50. Id. at 2545 .

51. 130 S. Ct. 1577 (2010).

52. Stevens, $130 \mathrm{~S}$. Ct. at 1585.

53. See, e.g., New York v. Ferber, 458 U.S. 747, 763-64 (1982) (“[I]t is not rare that a content-based classification of speech has been accepted because it may be appropriately generalized that within the confines of the given classification, the evil to be restricted so overwhelmingly outweighs the expressive interests, if any, at stake, that no process of case-by-case adjudication is required.").

54. Stevens, $130 \mathrm{~S}$. Ct. at 1586.

55. Id.

56. See id. at 1584-86.

57. 505 U.S. 833 (1992).

58. 410 U.S. 113, 163-66 (1973). 
an application of law to specific facts presented for adjudication. It was an abstract and generalized set of instructions for handling future cases.

In Casey, the Court preserved Roe's "central holding" that "viability marks the earliest point at which the State's interest in fetal life is constitutionally adequate to justify a legislative ban on nontherapeutic abortions." 59 At the same time, a plurality of justices jettisoned the trimester framework, which they did "not consider to be part of the essential holding of Roe."60 That distinction, which Justice Scalia criticized as a "new, keep-what-youwant-and-throw-away-the-rest version" of stare decisis, reflected a view that core holdings are entitled to very different treatment than peripheral exposition. ${ }^{61}$

The lower federal courts also furnish some notable support for policing the line between holdings and dicta. Judge Boggs has written that "the holding/dicta distinction demands that we consider binding only that which was necessary to resolve the question before the [Supreme] Court."62 Likewise, Judge Leval has contended that Supreme Court dicta are "not law."63 In his estimation, the consequence is not merely that inferior-court judges should feel free to depart from such dicta. The implications go further: judges "may not treat the Supreme Court's dictum as dispositive." 64 A judge who does so "fail[s] to discharge" her "responsibility to deliberate on and decide the question which needs to be decided." 65 Judge Aldisert has taken a similar position, reasoning that " $[t]$ he common-law tradition requires starting with a narrow holding and, then ... e either applying it or not applying it to subsequent facts." 66 Examples like these demonstrate the continued relevance of the classic holding-dicta distinction to American jurisprudence.

\section{Precedential Breadth at the Supreme Court}

Given the persistence of the holding-dicta distinction, one might infer that the scope of precedent is commonly defined in a narrow fashion. After

59. Casey, 505 U.S. at 860 .

60. Id. at 873 (plurality opinion).

61. Id. at 993 (Scalia, J., concurring in the judgment in part and dissenting in part).

62. Grutter v. Bollinger, 288 F.3d 732, 787 (6th Cir. 2002) (en banc) (Boggs, J., dissenting), affd, 539 U.S. 306 (2003).

63. Pierre N. Leval, Judging Under the Constitution: Dicta About Dicta, 81 N.Y.U. L. Rev. 1249,1274 (2006).

64. Id.

65. Id. at 1250; of. United States v. Crawley, 837 F.2d 291, 292 (7th Cir. 1988) ("What is at stake in distinguishing holding from dictum is that a dictum is not authoritative. It is the part of an opinion that a later court, even if it is an inferior court, is free to reject.").

66. Ruggero J. Aldisert, Precedent: What It Is and What It Isn't; When Do We Kiss It and When Do We Kill It?, 17 PEPp. L. Rev. 605, 610 (1990); cf. In re Am. Express Merchs.' Litig., 681 F.3d 139, 147 (2d Cir. 2012) (Jacobs, J., dissenting from denial of rehearing en banc) ("[E]ven if the ... dicta were to have the meaning the panel ascribes to it, it is nonetheless still dicta."). 
all, an insistence on separating holdings from dicta can be understood as reflecting discomfort with a broad conception of precedent.

In practice, however, the scope of precedent tends to be remarkably capacious. We can observe this phenomenon both at the Supreme Court, which is the topic of this Section, and in the lower federal courts, which are the topic of the next.

In examining the Supreme Court's broad conception of precedential scope, it will be instructive to consider the Court's treatment of four categories of propositions: (1) unmistakable dicta; (2) doctrinal frameworks; (3) codifying statements; and (4) supporting rationales.

\section{Unmistakable Dicta}

The Supreme Court sometimes cites its prior articulations of legal principles even while acknowledging those articulations as dicta. ${ }^{67}$ Such citations do not prove that dicta receive binding force, but they do suggest that the Court ascribes some significance to the fact that a principle has a historical lineage-in other words, that the Court values precedent qua precedenteven when the principle was expressed in dicta. ${ }^{68}$

Occasionally, the justices offer more explicit indications that dicta can carry binding force beyond their persuasive appeal. In Kappos v. Hyatt, the Supreme Court considered the treatment of new evidence in civil actions contesting the denial of patent applications. ${ }^{69}$ One of the precedents the Court discussed was Butterworth v. United States ex rel. Hoe, which described civil actions as independent of the initial patent application, with the consequence that new evidence could be presented in subsequent litigation. ${ }^{70}$ The Kappos Court characterized Butterworth's pronouncements as worthy of deference despite acknowledging that the relevant "discussion was not strictly necessary to Butterworth's holding."71 The Court explained that, although the pertinent statements in Butterworth were technically dicta, they were "not the kind of ill-considered dicta that we are inclined to ignore."72 To the contrary, the Butterworth discussion reflected a "careful[ ] examin[ation]" of

67. See, e.g., South Carolina v. North Carolina, 130 S. Ct. 854, 871 (2010) (Roberts, C.J., concurring in the judgment in part and dissenting in part) ("[W]e have strongly intimated in other decisions (albeit in dictum) that private entities can rarely, if ever, intervene in original actions involving the apportionment of interstate waterways."); Rivera v. Illinois, $129 \mathrm{~S}$. Ct. 1446,1455 (2009) ("We disavowed this statement . . . albeit in dicta . . . ").

68. On the distinctive purposes for which judges can use precedent, see Kozel, supra note 24 , at $1849-55$.

69. 132 S. Ct. 1690 (2012).

70. Kappos, 132 S. Ct. at 1698 (discussing Butterworth v. United States ex rel. Hoe, 112 U.S. $50(1884))$.

71. Id.

72. Id. 
the statutory context and inferior-court decisions. ${ }^{73}$ The Court had also "reiterated Butterworth's well-reasoned interpretation ... in three later cases." The dicta were therefore entitled to some degree of deference.

Kappos serves as a starting point in probing the barrier between binding holdings and dispensable dicta. It is difficult to discern precisely how much deference the Butterworth dicta received, because the Kappos Court also found them persuasive on the merits. ${ }^{75}$ But the central takeaway is the recognition of distinctions among different types of dicta in light of considerations such as their evident degree of deliberation. By distinguishing "illconsidered dicta" from dicta that ought not be "ignor[ed]," Kappos offers a subtle but significant challenge to the holding-dicta dichotomy. The case implies that even dicta can be worthy of deference under the right circumstances.

A comparable example comes from Justice Breyer's dissent in Parents Involved in Community Schools v. Seattle School District No. $1{ }^{76}$ In Parents Involved, the Supreme Court considered the authority of school districts to make school assignments based on factors including students' race. The Court struck down the relevant districts' practices as violating the Equal Protection Clause. ${ }^{77}$

Justice Breyer dissented on behalf of himself and three others, criticizing the treatment of precedent in a portion of the Court's opinion that was joined by a plurality of justices. In particular, Justice Breyer emphasized a statement from the 1970 case of Swann v. Charlotte-Mecklenburg Board of Education $^{78}$ that arguably expressed approval of race-based enrollment decisions made "in order to prepare students to live in a pluralistic society."79 The Parents Involved plurality had characterized that part of Swann as inapposite, outmoded, and nonbinding dicta. ${ }^{80}$ On the dicta point, Justice Breyer conceded that the statement "was not a technical holding in the case." 81 But he countered that the Swann Court "set forth its view prominently in an important opinion joined by all nine Justices, knowing that it would be read and followed throughout the Nation." 82 In addition, the statement had come

73. Id.

74. Id.

75. See id. (describing the Butterworth approach as "well-reasoned").

76. 551 U.S. 701 (2007).

77. Parents Involved, 551 U.S. at 710-11.

78. 402 U.S. 1,16 (1970).

79. Parents Involved, 551 U.S. at 823 (Breyer, J., dissenting) (quoting Swann, 402 U.S. at 16) (internal quotation marks omitted); see also James E. Ryan, The Supreme Court and Voluntary Integration, 121 HARV. L. Rev. 131, 137 (2006) (arguing that Swann "clearly endorsed the proposition that school officials have the authority to seek racial integration voluntarily").

80. See Parents Involved, 551 U.S. at 737-38 (plurality opinion).

81. Id. at 823 (Breyer, J., dissenting).

82. Id. at 831 . 
to enjoy "wide acceptance in the legal culture." ${ }^{83}$ And "it reflected a consensus that had already emerged among state and lower federal courts." ${ }^{44}$ The plurality's "rigid distinctions between holdings and dicta" were therefore insufficient. ${ }^{85}$ If the plurality wished to reconsider the statement in Swann, it should have acknowledged an obligation to "explain to the courts and to the Nation why it would abandon guidance set forth many years before." 86

Justice Breyer's language suggests that he regarded the Swann dicta as carrying something more than persuasive effect. In his view, it was not enough to ask whether the position taken in Swann was convincing on the merits. The statement deserved a degree of respect above and beyond its soundness. This status owed in part to the perceived intention of the issuing Court, and in part to the role that the statement came to play over time. Dicta or not, the statement constituted "authoritative legal guidance." 87 Departing from it accordingly required a better answer to the question, "[W]hy change?"88

As with the Court's opinion in Kappos, Justice Breyer's dissent in Parents Involved implies that, in certain situations, it is appropriate to defer to judicial statements even if they fall into the category of unnecessary dicta. Justice Breyer advanced the same basic position in a previous case, asserting in 2004 that dicta with a "lengthy history" can be entitled to deference if they are "the kind of strong dicta that the legal community typically takes as a statement of the law." ${ }^{99}$ Similar sentiments appear in a 2008 opinion from Justice Souter contending that, even if a particular statement was technically a dictum, "it was dictum well considered, and it stated the view of five Members of this Court."90 The common theme is that not all dicta are created equal; some are entitled to precedential weight.

\section{Doctrinal Frameworks}

By their very nature, doctrinal frameworks sweep far beyond the facts at hand to address other situations not concurrently before the court. Yet while Supreme Court justices occasionally refuse to accept the validity of doctrinal frameworks with which they disagree, ${ }^{91}$ in many cases the frameworks are

83. Id. at 823 (quoting Dickerson v. United States, 530 U.S. 428,443 (2000)) (internal quotation marks omitted).

84. Id. at 827 .

85. Id. at 831 .

86. Id.

87. Id.

88. This language is drawn from a recent dissent by Justice Breyer dealing with shifts in administrative policy. See FCC v. Fox Television Stations, Inc., 129 S. Ct. 1800, 1832 (2009) (Breyer, J., dissenting).

89. Hiibel v. Sixth Judicial Dist. Court, 542 U.S. 177, 198 (2004) (Breyer, J., dissenting).

90. Boumediene v. Bush, 553 U.S. 723, 799 (2008) (Souter, J., concurring).

91. See, e.g., State Farm Mut. Auto. Ins. Co. v. Campbell, 538 U.S. 408, 429 (2003) (Scalia, J., dissenting) ("I adhere to the view expressed in my dissenting opinion in $B M W$ of 
taken as given, with the real differences concerning their application to particular sets of facts..$^{92}$ Disputes over the Commerce Clause tend to accept the relevance of asking whether "economic activity substantially affects commerce." ${ }^{33}$ Disputes over racial classifications generally assume that the appropriate question is whether the government has narrowly tailored its regulations to serve a compelling interest..$^{94}$ Disputes over the Ex Post Facto Clause give canonical force to Justice Chase's four categories of prohibited laws as articulated in Calder v. Bull..$^{95}$ Disputes over administrative law accept the two-step protocol set forth in Chevron U.S.A. Inc. v. Natural Resources Defense Council, Inc. ${ }^{96}$ as appropriate for a large chunk of cases..$^{97}$ In these and scores of other situations, generalized doctrinal frameworks exert binding force.

An illuminating example recently arose in the context of firearm regulation. In the Slaughter-House Cases, decided in 1873, the Supreme Court interpreted the Fourteenth Amendment's Privileges or Immunities Clause ${ }^{98}$ as

North America, Inc. v. Gore, 517 U.S. 559, 598-599 (1996), that the Due Process Clause provides no substantive protections against 'excessive' or 'unreasonable' awards of punitive damages.").

92. See Caminker, supra note 43 , at 14 (1994) (" $[\mathrm{J}]$ urists generally agree that legal rules or doctrines invoked by a judge to justify her disposition of a case qualify for precedential status.").

93. Compare United States v. Lopez, 514 U.S. 549, 560 (1995) ("Where economic activity substantially affects interstate commerce, legislation regulating that activity will be sustained."), with id. at 615-16 (Breyer, J., dissenting) (arguing that the commerce power "encompasses the power to regulate local activities insofar as they significantly affect interstate commerce" and pointing out that "to speak of 'substantial effect' rather than 'significant effect' would make no difference in this case"). See also id. at 585 (Thomas, J., concurring) ("In an appropriate case, I believe that we must further reconsider our 'substantial effects' test with an eye toward constructing a standard that reflects the text and history of the Commerce Clause without totally rejecting our more recent Commerce Clause jurisprudence.").

94. Compare Grutter v. Bollinger, 539 U.S. 306, 326 (2003) (stating that racial "classifications are constitutional only if they are narrowly tailored to further compelling governmental interests"), with id. at 378 (Rehnquist, C.J., dissenting) ("I agree with the Court that, in the limited circumstance when drawing racial distinctions is permissible,' the government must ensure that its means are narrowly tailored to achieve a compelling state interest.").

95. See, e.g., Peugh v. United States, 133 S. Ct. 2072, 2081 (2013) (citing Calder v. Bull, 3 U.S. (3 Dall.) 386, 390 (1798)).

96. 467 U.S. 837 (1984).

97. See, e.g., City of Arlington v. FCC, 133 S. Ct. 1863, 1868 (2013) ("As this case turns on the scope of the doctrine enshrined in Chevron, we begin with a description of that case's now-canonical formulation."); Abbe R. Gluck, The States as Laboratories of Statutory Interpretation: Methodological Consensus and the New Modified Textualism, 119 YALE L.J. 1750, 1817 (2010) ("Chevron is precedential for much more than its mere substantive (environmental law) holding; far more significant has been the methodology it sets forth for all future potential deference cases." (footnote omitted)).

98. U.S. CoNst. amend. XIV, $\$ 1$ ("No State shall make or enforce any law which shall abridge the privileges or immunities of citizens of the United States ...."). 
protecting "only those rights 'which owe their existence to the Federal government, its National character, or its laws." "99 That opinion was eventually characterized by many as undermining the argument that the Privileges or Immunities Clause incorporates the Bill of Rights against the states. ${ }^{100}$ The Court's eventual response was the "selective incorporation" of most of the Bill of Rights via the Fourteenth Amendment's Due Process Clause. ${ }^{101}$ The inquiry became whether a particular right is "fundamental to our scheme of ordered liberty and system of justice."102

The validity of selective incorporation under the Due Process Clause reemerged in McDonald v. City of Chicago, which involved local laws banning the possession of handguns in the home. The Court had recently invalidated a comparable District of Columbia law as violating the Second Amendment. ${ }^{103}$ The question in McDonald was whether the same analysis should apply to state and local laws. The challengers asked the Court to depart from the practice of selective incorporation under the Due Process Clause and to rule that the Second Amendment should be applied to state and local governments via the Privileges or Immunities Clause. ${ }^{104}$ But a plurality of justices declined the invitation. The plurality conceded that "many legal scholars dispute the correctness of the narrow Slaughter-House interpretation." 105 Yet it chose to continue down the path of Due Process Clause analysis. ${ }^{106}$

The McDonald opinion evinces a broad understanding of precedential scope. The Supreme Court's selective incorporation doctrine is a wide-ranging framework designed to apply to cases dealing with a host of constitutional rights. Nevertheless, the McDonald plurality treated the framework as entitled to deference despite forceful criticisms-criticisms that the plurality did not attempt to rebut-of its soundness on the merits. The McDonald

99. McDonald v. City of Chicago, 130 S. Ct. 3020, 3028 (2010) (quoting the SlaughterHouse Cases, 83 U.S. 36, 79 (1873)).

100. Cf. Jamal Greene, The Anticanon, 125 Harv. L. Rev. 379, 394 n.80 (2011) ("[M]any constitutional scholars believe that the Court improperly failed to interpret the Privileges or Immunities Clause of the Fourteenth Amendment as applying the Bill of Rights to state and local action."). But see Kurt T. Lash, The Fourteenth Amendment and the Privileges AND ImMunities of AMERICAN Citizenship 264-65 (2014) (arguing that it was not the Court's approach in the Slaughter-House Cases, but rather its subsequent opinion in United States v. Cruikshank, 92 U.S. 542 (1876), that led to a constrained interpretation of the Privileges or Immunities Clause).

101. McDonald, $130 \mathrm{~S}$. Ct. at 3034.

102. Id. (emphasis omitted).

103. See District of Columbia v. Heller, 554 U.S. 570, 635 (2008) (holding that the "ban on handgun possession in the home violates the Second Amendment, as does its prohibition against rendering any lawful firearm in the home operable for the purpose of immediate selfdefense").

104. See McDonald, $130 \mathrm{~S}$. Ct. at 3028.

105. Id. at 3029.

106. Id. at 3030-31. 
opinion thus stands as another endorsement of the view that the Court possesses considerable authority to articulate generalized doctrinal frameworks that will be imbued with precedential effect.

Even some cases that ostensibly suggest a more restrictive understanding of precedent ultimately accept the constraining force of doctrinal frameworks. Recall the example of Casey, which preserved the constitutional right to abortion while rejecting the trimester framework set forth in Roe $v$. Wade. ${ }^{107}$ Casey drew a clear line between Roe's central holding and its other constituent elements, but the plurality did not stop there. Instead, it embraced a different doctrinal framework - one focused on whether a regulation places an "undue burden" on abortion rights ${ }^{108}$-as the proper analytical rubric to replace the disfavored trimester approach. In describing its preferred rubric, the plurality also explained that "[r]egulations which do no more than create a structural mechanism" for "express[ing] profound respect for the life of the unborn are permitted," so long as "they are not a substantial obstacle to the woman's exercise of the right to choose." 109 In effect, the Casey plurality treated Roe's trimester framework as unworthy of deference while endorsing an alternative framework to guide future courts. What began as a relatively restrictive approach to precedent gave way to a far more inclusive paradigm.

\section{Codifying Statements}

Related to the crafting of broad doctrinal frameworks is the Supreme Court's practice of couching some of its directives in remarkably elaborate terms. There is no better illustration of such a "codifying decision[ ]"10 than Miranda v. Arizona, which announced a detailed litany of warnings to serve as "procedural safeguards" during custodial interrogations of suspected criminals. ${ }^{111}$ As Judge Easterbrook has noted, the Miranda warnings theoretically "could be disregarded on the ground that Ernesto Miranda had not been given any warning, so the Court could not pronounce on the consequences of giving three but not four of the warnings on its list."112 And yet the Supreme Court has treated the warnings as representing a binding mandate of criminal procedure. ${ }^{113}$

107. See supra Section I.B.

108. Planned Parenthood of Se. Pa. v. Casey, 505 U.S. 833, 878 (1992) (plurality opinion).

109. Id. at 877 .

110. Faheem-El v. Klincar, 841 F.2d 712, 730 (7th Cir. 1988) (en banc) (Easterbrook, J., concurring).

111. 384 U.S. $436,444-45$ (1966).

112. Faheem-El, 841 F.2d at 730 .

113. See id.; see also Dickerson v. United States, 530 U.S. 428, 444 (2000) ("Miranda announced a constitutional rule that Congress may not supersede legislatively."); id. at 435 (The Miranda guidelines "established that the admissibility in evidence of any statement given during custodial interrogation of a suspect would depend on whether the police provided the suspect with four warnings."). 
Like doctrinal frameworks, codifying statements float free of the factual context surrounding any particular dispute. But even though they are broad statements of guiding principles, they can exert binding force as a matter of federal practice. Once again, the effect is to expand the constraining power of the Supreme Court's decisions.

\section{Supporting Rationales}

The reasons offered to support a judicial ruling are distinct from the ruling itself. Some conceptions of precedent are broad enough to treat supportive reasoning as carrying binding force. ${ }^{114}$ On other accounts, judicial rationales should not receive deference when they are exported to new factual contexts that were not before the issuing court at the time of its decision. The latter position reflects the belief that "under the doctrine of stare decisis a case is important only for what it decides-for the 'what,' not for the 'why,' and not for the 'how." "115

The debate has been with us for decades. In 1928, Professor Oliphant lamented that "we are well on our way toward a shift from following decisions to following so-called principles, from stare decisis to . . stare dictis."116 Justice Kennedy took a contrary position some sixty years later in stating that "the principle of stare decisis directs us to adhere not only to the holdings of our prior cases, but also to their explications of the governing rules of law."117

That latter view is most consistent with the Supreme Court's characterization of its contemporary practice. The Court has stated that a "well-established rationale upon which the Court based the results of its earlier decisions" is entitled to stare-decisis effect. ${ }^{118}$ As explained above, the Court has not been uniform in its solicitude for underlying rationales, and there are notable examples in which articulated reasons are denied deference. ${ }^{119}$ But in other cases, rationales continue to exert binding force. ${ }^{120}$

114. See Leval, supra note 63, at 1256 ("If the court's judgment and the reasoning which supports it would remain unchanged, regardless of the proposition in question, that proposition . . . is superfluous to the decision and is dictum." (emphasis added)).

115. In re Osborne, 76 F.3d 306, 309 (9th Cir. 1996) (making the quoted statement in the context of circuit precedent); Aldisert, supra note 66, at 607.

116. Herman Oliphant, A Return to Stare Decisis, 14 A.B.A. J. 71, 72 (1928).

117. Cnty. of Allegheny v. ACLU, 492 U.S. 573, 668 (1989) (Kennedy, J., concurring in the judgment in part and dissenting in part); see also Local 28, Sheet Metal Workers' Int'l Ass'n v. EEOC, 478 U.S. 421, 490 (1986) (O'Connor, J., concurring in part and dissenting in part) ("Although technically dicta, the discussion [of a relevant statute in a previous decision] was an important part of the Court's rationale for the result it reached, and accordingly is entitled to greater weight than the Court gives it today.").

118. Seminole Tribe of Fla. v. Florida, 517 U.S. 44, 66-67 (1996).

119. See supra Section I.B.

120. E.g., Seminole Tribe of Fla., 517 U.S. at 66. 


\section{Precedential Breadth in the Lower Federal Courts}

The inclusive view of precedent is even more prevalent in the lower federal courts. This Part has identified prominent federal judges who have endorsed a fairly restrictive approach to precedent. ${ }^{121}$ Yet the attitude exemplified by those judges is far from universal. ${ }^{122}$ As Professor Schauer observes, it is often true that, within "interpretive arenas below the Supreme Court, one good quote is worth a hundred clever analyses of the holding."123 From the determined efforts of lower-court judges to "parse Supreme Court opinions in seeking to identify applicable doctrine," it can seem as if there is "little meaningful difference between the effect of a congressional statute[ ] and a new doctrinal rule adopted by the Court."124

Many lower courts have described Supreme Court statements as entitled to deference even when those statements were made in dicta. ${ }^{125}$ The strength of deference varies from court to court. Some lower courts describe Supreme Court dicta as akin to Supreme Court holdings, such that dicta can demand adherence in what would otherwise "be an extremely close case."126 Other opinions contemplate an intermediate degree of deference, ${ }^{127}$ with judges asserting that Supreme Court dicta bind "almost as firmly" as holdings. ${ }^{128}$ Still other courts describe dicta as entitled to "considerable weight"

121. See supra Section I.B.

122. See Caminker, supra note 43 , at 75 ("[L]ower courts frequently give considerable, and sometimes even dispositive, weight to nonbinding but well-considered dicta when addressing novel legal questions." (footnotes omitted)); Dorf, supra note 14, at 2026 ("Some lower courts do not view themselves as bound by a higher court's dicta, while others take the position that all considered statements of a higher court are binding." (footnote omitted)).

123. Frederick Schauer, Opinions as Rules, 53 U. CHI. L. Rev. 682, 683 (1986) (book review); see also id. ("II]t is not what the Supreme Court held that matters, but what it said.").

124. Ashutosh Bhagwat, Separate but Equal?: The Supreme Court, the Lower Federal Courts, and the Nature of the "Judicial Power", 80 B.U. L. Rev. 967, 994 (2000); see also id. ("[T]he traditional judicial distinction between dictum and a holding seems to play an increasingly insignificant role in the Court's opinions formulating the 'rule' that they create, and subsequently in lower courts' decisions analyzing and applying those rules.").

125. See, e.g., McCravy v. Metro. Life Ins. Co., 690 F.3d 176, 181 n.2 (4th Cir. 2012); ACLU of Ky. v. McCreary Cnty., 607 F.3d 439, 447 (6th Cir. 2010); Schwab v. Crosby, 451 F.3d 1308, 1325 (11th Cir. 2006); Stone Container Corp. v. United States, 229 F.3d 1345, 1349-50 (Fed. Cir. 2000); United States v. Oakar, 111 F.3d 146, 153 (D.C. Cir. 1997); Town Sound \& Custom Tops, Inc. v. Chrysler Motors Corp., 959 F.2d 468, 495 n.41 (3d Cir. 1992); United States v. Miller, 604 F. Supp. 2d 1162, 1167 (W.D. Tenn. 2009) (noting that while "[c]ourts generally treat dicta in case law as non-binding ... [m]ost federal circuits have recognized that 'by the way' statements made by the Supreme Court resonate more forcefully than dicta from other sources"); Aaron-Andrew P. Bruhl, Hierarchy and Heterogeneity: How to Read a Statute in a Lower Court, 97 CoRnell L. Rev. 433, 479 (201.2) ("[T] he lower courts . . tend to treat the high court's dicta as quite authoritative, indeed nearly binding.").

126. Myers v. Loudoun Cnty. Pub. Sch., 418 F.3d 395, 410 (4th Cir. 2005) (Motz, J., concurring in the judgment).

127. See Caminker, supra note 43, at 76 (arguing that "the courts giving significant weight to dicta make it quite clear that they do not consider dicta to be binding as they do unifiedmajority dispositional rules").

128. McCoy v. Massachusetts, 950 F.2d 13, 19 (1st Cir. 1991). 
but add that "we are not necessarily bound to follow" them. ${ }^{129}$ Another court has noted that, while dicta are "not binding," neither can they be taken "lightly" - although they may give way in the face of unanticipated circumstances. ${ }^{130}$ And the descriptions do not end here; lower courts also refer to Supreme Court dicta using words like "respect,"131 "great weight,"132 "great deference," 133 and "more appropriate ... than any test we might fashion." 134

Statements of this sort, which disavow the treatment of Supreme Court dicta as unworthy of deference, expressly adopt an inclusive paradigm of precedent. Rather than being denied any weight beyond their persuasiveness, Supreme Court dicta receive substantial, and sometimes controlling, deference in the lower courts. ${ }^{135} \mathrm{~A}$ recent empirical study by Professor Klein and Professor Devins underscores this point by confirming the "frequent decisions" among inferior courts "to abide by statements from higher courts even though they are recognized as dicta."136 Whatever its merits as a normative matter-an issue that will be taken up in Part III, below-the practice of deferring to dicta provides a final, and striking, piece of evidence for the inclusive paradigm's resonance in contemporary practice.

\section{Clarifying the Inclusive Paradigm of Precedent}

The previous Part explained the ways in which the prevailing approach to Supreme Court precedent is broadly inclusive. Generalized, sweeping, and unnecessary propositions commonly exert forward-looking effect in the Supreme Court and lower courts alike.

The crucial normative questions are whether the prevalence of this inclusive paradigm is something to be cheered or lamented, and how the legal system should respond to the tension between the inclusive paradigm and the more restrictive definition of precedent that is implied by the classic holding-dicta distinction. These questions provide the backdrop for the remainder of the Article.

To facilitate the process of normative evaluation, this Part clarifies three aspects of the inclusive paradigm of precedent. To summarize:

129. United States v. Bell, 524 F.2d 202, 206 \& n.4 (2d Cir. 1975).

130. Official Comm. of Unsecured Creditors of Cybergenics Corp. ex rel. Cybergenics Corp. v. Chinery, 330 F.3d 548, 561 (3d Cir. 2003) (en banc).

131. Nichol v. Pullman Standard, Inc., 889 F.2d 115, 120 n.8 (7th Cir. 1989).

132. See, e.g., Coeur D'Alene Tribe of Idaho v. Hammond, 384 F.3d 674, 683 (9th Cir. 2004); United States v. Santana, 6 F.3d 1, 9 (Ist Cir. 1993).

133. United States v. Colasuonno, 697 F.3d 164, 179 (2d Cir. 2012).

134. Grutter v. Bollinger, 288 F.3d 732, 746 n.9 (6th Cir. 2002) (en banc), aff d, 539 U.S. 306 (2003).

135. See Caminker, supra note 43 , at 76 ("It is . . quite clear that courts do not follow dicta merely because they are moved by the dicta's intrinsic persuasive force; courts occasionally follow dicta with which they expressly disagree.").

136. Klein \& Devins, supra note 17 , at 2044 . 
First, the inclusive paradigm is not boundless. Even with the inclusive approach, there remain some judicial propositions that fall beyond the limits of deference.

Second, the inclusive paradigm is not necessarily binary. It is possible to conceptualize the inclusive paradigm as a continuum in which the strength of precedent varies according to the centrality of a given judicial proposition. That possibility does not eliminate the need for investigating the underlying justifications for precedential strength; to the contrary, it makes the need more acute.

Third, the inclusive paradigm does not focus on the holding-dicta distinction. Certain broad propositions that receive deference from future courts may plausibly be characterized as holdings that were logically necessary to the decisions that announced them. But characterizing a statement as a judicial holding does not end the inquiry into its binding force. There remains the deeper question of why a statement's nature as holding or dicta should determine its forward-looking effect.

\section{A. Inclusive Versus Infinite}

The inclusive paradigm of precedent need not imply that everything a prior court says will have constraining force in future adjudication. Despite permitting precedents to sweep broadly, the inclusive paradigm is compatible with the view that some judicial propositions are unworthy of deference.

In particular, a precedent's scope of applicability may take account of the difference between deliberate and offhand language. Thus, in the Kappos case discussed above, it was important to the Supreme Court that its predecessor Court appeared to have "carefully examined" an issue before opining in dicta. ${ }^{137}$ Where indicia of deliberation are apparent, courts naturally are more inclined to credit past statements despite their nonessential or generalized nature. ${ }^{138}$ Relevant factors include "earmarks of deliberative thought purposefully expressed" 139 such as "the sophistication of [the] analysis" and "verbal cues as to the author's commitment to the idea[s]." 140 Conversely, where judicial utterances are entirely disconnected from the facts at hand, "made casually and without analysis," or "uttered in passing without due consideration of the alternatives," 141 deference may be improper even under the inclusive paradigm. The same may be true when statements are "buried

137. Kappos v. Hyatt, 132 S. Ct. 1690, 1699 (2012).

138. See, e.g., Schwab v. Crosby, 451 F.3d 1308, 1325 (11th Cir. 2006) ("This is not subordinate clause, negative pregnant, devoid-of-analysis, throw-away kind of dicta. It is well thought out, thoroughly reasoned, and carefully articulated analysis by the Supreme Court describing the scope of one of its own decisions.").

139. United States v. Santana, 6 F.3d 1, 9 (1st Cir. 1993).

140. Caminker, supra note 43 , at 47 .

141. United States v. Johnson, 256 F.3d 895, 915 (9th Cir. 2001) (en banc) (opinion of Kozinski, J.). 
in a footnote" rather than prominently announced. ${ }^{142}$ The simple point is that, notwithstanding its breadth, even the inclusive paradigm has limits.

\section{B. Dichotomy Versus Continuum}

The inclusive paradigm is compatible with the view that the strength of precedent is a fluid continuum rather than a binary proposition. For example, it may be that, while nonessential statements or broad generalizations warrant some deference under the inclusive paradigm, they do not warrant the same level of deference that is accorded to statements closely tethered to the adjudicated facts. Several federal courts of appeals adopt this approach by describing Supreme Court dicta as entitled to a reduced level of deference as compared with the Court's holdings. ${ }^{143}$

We might understand the Supreme Court's treatment of its own dicta as reflecting a similar sentiment. Most dicta receive no deference from the Court, but some-such as dicta that are expressed unequivocally and with evident deliberation-receive at least a measure of deference beyond their persuasive value, even if they do not enjoy the stronger deference reserved for holdings. ${ }^{144}$

The puzzle is why a jurist would opt for such a continuum-based model rather than a binary approach to precedent. There are several potential answers. Perhaps the judge is primarily concerned about error costs and believes that, although nonessential statements carry greater risks of error than essential statements, the effect is gradual as one moves away from a decision's core and toward its conceptual outskirts. ${ }^{145}$ Or perhaps the judge accepts the need for superior courts to guide inferior courts but believes that the utility of guidance tends to decrease-again, gradually-for propositions that are closer to a precedent's periphery than its core. ${ }^{146}$ As explained below, the validity of these arguments depends on underlying issues of interpretive methodology and constitutional theory. But regardless of how the underlying debates are resolved, the inclusive paradigm neither requires nor forecloses the possibility that different types of propositions may receive different levels of deference. The inclusive paradigm demands only that a wide array of propositions receive some deference beyond their persuasive value. ${ }^{147}$

142. Groh v. Ramirez, 540 U.S. 551, 574 (2004) (Thomas, J., dissenting); accord Hohn v. United States, 524 U.S. 236, 259-60 (1998) (Scalia, J., dissenting) (criticizing the Court for relying on "mere dictum ... (and dictum in a footnote, at that)").

143. See supra Section I.D.

144. See supra Section I.C.1.

145. See infra Section IV.B.

146. See infra Section IV.B.

147. Cf. Schauer, supra note 29, at 1943 ("[I]f an agent is genuinely persuaded of some conclusion because she has come to accept the substantive reasons offered for that conclusion by someone else, then authority has nothing to do with it."). 


\section{Superficial Labels Versus Theoretical Drivers}

The point of studying the inclusive paradigm is not to determine whether the various judicial statements that receive binding effect in contemporary practice are properly labeled as "holdings" under some definition of that term. ${ }^{148}$ Even if a doctrinal framework or sweeping rationale is characterized as necessary to the decision that contains it, there remains the question of whether the proposition should bind future courts. The answer to that question is exogenous to the holding-dicta distinction. It requires an appeal to something deeper.

In cases where the deeper explanations for deference are either missing altogether or so undertheorized as to remain opaque, judges are exposed to charges of invoking the language of precedent to paper over "stealth" machinations ${ }^{149}$ and "result-oriented expedient [s]." 150 To draw on Justice Scalia's dissent in United States $v$. Windsor, there arises a concern that the only real constraint is a court's "sense of what it can get away with." 151 This is not to say that there is no internal logic to the treatment of precedent; only that, if such logic exists, it lingers below the surface of judicial exposition. ${ }^{152} \mathrm{My}$ aim in the following Parts is to bring that logic-and its implications-out into the open.

\section{Reconceptualizing Precedential Scope}

Bearing in mind the foregoing description of the inclusive paradigm of precedent, we can turn to the projects of normative evaluation (in this Part) and doctrinal reform (in the next).

\section{A. Distinguishing the Horizontal and Vertical Spheres}

To construct a normative account of precedential scope, we must first distinguish between the vertical constraint of lower courts and the horizontal constraint of the Supreme Court itself.

148. Cf. Monaghan, supra note 14, at 763 ("The precedent has been viewed as limited to the 'decision' on the 'material facts' as seen by the precedent court, or the same as seen by the nonprecedent court; for others, the term means the 'rules' formulated by the precedent court; for still others, the term includes the reasons given for the rules formulated." (footnotes omitted)).

149. Barry Friedman, The Wages of Stealth Overruling (With Particular Attention to Miranda v. Arizona), 99 Geo. L.J. 1 (2010); see also Aziz Z. Huq, Removal as a Political Question, 65 Stan. L. Rev. 1, 19 (2013) (describing the "Roberts Court's habit of approaching disfavored precedents obliquely, gradually undermining them by 'stealth overruling").

150. Lawrence v. Texas, 539 U.S. 558, 592 (2003) (Scalia, J., dissenting).

151. 133 S. Ct. 2675, 2709 (2013) (Scalia, J., dissenting).

152. Cf. Fallon, supra note 14, at 125 (arguing that "matters of background principle" remain crucial to adjudication even when they are "submerged"). 


\section{Vertical Constraint}

The principles that define a precedent's scope of applicability will determine its vertical, or hierarchical, ${ }^{153}$ power to constrain inferior courts. The effect is especially pronounced in legal systems, such as the American federal system, that treat vertical precedent as absolutely binding. As the Supreme Court regularly reaffirms, it alone has the power to "overrule one of its precedents." 154 Where a Supreme Court holding applies to a pending dispute, an inferior court has only one available course of action. It must issue whatever ruling the holding indicates. There is no room for acting on doubts about the precedent's soundness or making predictions about the Supreme Court's eventual change of heart. ${ }^{155}$ An inferior court may not even depart from precedents that the Supreme Court has called into question. ${ }^{156}$ Absent a formal overruling, Supreme Court decisions remain indefeasibly binding on all inferior tribunals; finding a precedent to be controlling brings the inquiry to its end. ${ }^{157}$ Like the fateful brigade immortalized by Tennyson, inferior courts faced with controlling precedents are not permitted "to reason why." 158

As we have seen, the situation is different with respect to Supreme Court dicta. Inferior courts commonly treat the Supreme Court's statements as binding even when those statements are unmistakable dicta. ${ }^{159}$ Crucially, however, lower courts at least contemplate the possibility of departing from Supreme Court dicta in light of countervailing considerations. ${ }^{160}$ And for

153. See, e.g., Evan H. Caminker, Why Must Inferior Courts Obey Superior Court Precedents?, 46 Stan. L. Rev. 817, 823-24 (1994).

154. State Oil Co. v. Khan, 522 U.S. 3, 20 (1997); see also Agostini v. Felton, 521 U.S. 203, 237 (1997) ("We do not acknowledge, and we do not hold, that other courts should conclude our more recent cases have, by implication, overruled an earlier precedent.").

155. See, e.g., Lawrence B. Solum, The Supreme Court in Bondage: Constitutional Stare Decisis, Legal Formalism, and the Future of Unenumerated Rights, 9 U. PA. J. Const. L. 155, 188 (2006).

156. See, e.g., Roper v. Simmons, 543 U.S. 551, 594 (2005) (O'Connor, J., dissenting) (" $[\mathrm{I}] \mathrm{t}$ remains 'this Court's prerogative alone to overrule one of its precedents.' That is so even where subsequent decisions or factual developments may appear to have 'significantly undermined' the rationale for our earlier holding." (citation omitted) (quoting State Oil, 522 U.S. at 20, and United States v. Hatter, 532 U.S. 557, 567 (2001))). But cf. Minority Television Project, Inc. v. FCC, 736 F.3d 1192, 1213 (9th Cir. 2013) (en banc) (Kozinski, J., dissenting) (suggesting that the actual "lesson is, we must not get ahead of the Supreme Court-unless we're right").

157. See, e.g., Sanford Levinson, On Positivism and Potted Plants: "Inferior" Judges and the Task of Constitutional Interpretation, 25 ConN. L. Rev. 843, 848 (1993) ("The oath of constitutional fidelity, required of every public official by Article VI of the Constitution, is transformed, for the 'inferior' judge, into a duty to obey the Supreme Court.").

158. Lord Alfred Tennyson, The Charge of the Light Brigade (1854), reprinted in Poems of English Heroism 118 (Arthur Compton Auchmuty ed., London, Kegan Paul, Trench, Trübner \& Co. 1895) ("Their's not to make reply, / Their's not to reason why, / Their's but to do and die.").

159. See supra Section I.D.

160. See supra Section I.D. 
those (relatively few) courts and judges who do not recognize Supreme Court dicta as entitled to any deference beyond its persuasiveness, there is even greater room for blazing a new trail.161

\section{Horizontal Constraint}

Precedent plays a different role when the context shifts from hierarchical interactions among tribunals of varying rank to the Supreme Court's "horizontal" relationship with its past self.

As a doctrinal matter, the pivotal distinction between vertical precedent and horizontal precedent is that, while the former is absolutely binding, the latter is not. The Supreme Court regularly emphasizes that horizontal precedent plays a substantial role in its decisionmaking process. Indeed, the Court has declared that some "special justification" beyond a precedent's wrongness is required in order to warrant an overruling. ${ }^{162}$ Yet the Court also cautions that its commitment to precedent is flexible, discretionary, and rebuttable. ${ }^{163}$ It claims, and regularly exercises, the power to overrule its precedents even when they are squarely on point. High-profile examples in recent years include Citizens United $v$. FEC ${ }^{164}$ in the campaign-finance context and Lawrence $v$. Texas ${ }^{165}$ in the context of same-sex rights.

Unlike the U.K. House of Lords, which formerly described itself as inexorably committed to follow its precedents, ${ }^{166}$ the U.S. Supreme Court has acknowledged no such duty. Much of the time, it will abide by its past decisions. Other times, it will not.

\section{B. The Costs and Benefits of Constraint}

The next step is analyzing the costs and benefits of constraint in both the vertical and horizontal domains.

\section{Potential Benefits of Constraint}

In the vertical context, precedential constraint facilitates hierarchical control, judicial efficiency, and the dissemination of guidance to lower

161. See supra Section I.B.

162. See, e.g., Citizens United v. FEC, 130 S. Ct. 876, 920 (2010) (Roberts, C.J., concurring); Arizona v. Rumsey, 467 U.S. 203, 212 (1984); $c f$. Planned Parenthood of Se. Pa. v. Casey, 505 U.S. 833, 864 (1992) ("[A] decision to overrule should rest on some special reason over and above the belief that a prior case was wrongly decided.").

163. See, e.g., Payne v. Tennessee, 501 U.S. 808, 827-28 (1991) ("[W]hen governing decisions are unworkable or are badly reasoned, 'this Court has never felt constrained to follow precedent.'” (quoting Smith v. Allwright, 321 U.S. 649, 665 (1944))).

164. Citizens United, 130 S. Ct. at 886 (overruling Austin v. Mich. Chamber of Commerce, 494 U.S. $652(1990)$ ).

165. 539 U.S. 558 (2003) (overruling Bowers v. Hardwick, 478 U.S. 186 (1986)).

166. See Practice Statement (Judicial Precedent), [1966] 1 W.L.R. 1234 (Eng.) (noting, and "modiflying]," the House of Lords's prior practice of refusing to depart from precedent). 
courts. ${ }^{167}$ When precedents are construed broadly, more issues are removed from the sphere of reasonable debate. Inferior courts are obliged to treat those issues as off the table regardless of any substantive reservations. Such a "maximalist" 168 view of precedent can reduce decision costs for subsequent courts by increasing the number of propositions that must be taken as given. A judge might bristle at the fact that she has no authority to depart from the Supreme Court's utterances, just as a lawyer might lament the fact that inferior courts are powerless to accept an argument in favor of overruling. But the lack of discretion simplifies proceedings in the inferior courts and streamlines the resolution of disputes. ${ }^{169}$

Further, vertical constraint promotes adjudicative uniformity across different courts, jurisdictions, and geographic regions. ${ }^{170}$ Broad vertical constraint should lead to fewer lower-court anomalies that the Supreme Court will need to bring into line (or allow to linger). This feature can be particularly attractive when the incidence of superior-court review is infrequent, as is the case at the U.S. Supreme Court due to its light docket. ${ }^{171}$ Adjudicative uniformity is arguably a good in itself as a facilitator of the fair and equitable treatment of similarly situated parties. ${ }^{172}$ It is also a means of enhancing the legal regime's predictability for litigants, attorneys, and other stakeholders.

The benefits of following precedent are different in the horizontal context, where the Supreme Court grapples with the impact of its own past decisions. For starters, the control rationale that plays a pivotal role in the vertical context disappears with respect to horizontal precedent. Although

167. See, e.g., Hutto v. Davis, 454 U.S. 370, 375 (1982) (per curiam) ("[U]nless we wish anarchy to prevail within the federal judicial system, a precedent of this Court must be followed by the lower courts no matter how misguided the judges of those courts may think it to be.").

168. For a prominent articulation of the concept of maximalism, see CAss R. SUNSTEIN, One Case at a Time: Judicial Minimalism on the Supreme Court 9-10 (1999) (defining maximalists as "those who seek to decide cases in a way that sets broad rules for the future and that also gives ambitious theoretical justifications for outcomes").

169. Cf. id. at 48 ("A court that economizes on decision costs for itself may in the process 'export' decision costs to other people, including litigants and judges in subsequent cases who must give content to the law.").

170. See, e.g., Caminker, supra note 153, at 849 ("Both the Constitution's Framers and Supreme Court Justices have long recognized the importance of nationally uniform interpretations of federal law." (footnote omitted)).

171. See, e.g., Tara Leigh Grove, The Structural Case for Vertical Maximalism, 95 CoRNELL L. Rev. 1, 56-59 (2009); Ryan J. Owens \& David A. Simon, Explaining the Supreme Court's Shrinking Docket, 53 WM. \& MARY L. Rev. 1219, 1224 (2012) ("The Court decides fewer cases per Term now than at any other time in its modern history."); id. at 1228 (describing the diminishing docket size between 1940 and 2008).

172. See Caminker, supra note 153, at 852 ("National uniformity of federal law ensures that courts treat similarly situated litigants equally-a result often considered a hallmark of fairness in a regime committed to the rule of law."). But see Amanda Frost, Overvaluing Uniformity, 94 VA. L. Rev. 1567, 1588 (2008) ("Different readings of the same statute should . . no more threaten the integrity of the statute than different judicial choices regarding whether to certify a class, admit hearsay testimony, or grant a non-party's request for permissive intervention."). 
the efficient operation of the judicial system may require some Supreme Court control over inferior courts, it does not follow that the Supreme Court justices of today must be able to hem in the justices of tomorrow. In addition, the shift from vertical to horizontal precedent removes the interest in national uniformity. In horizontal operation, Supreme Court precedent does not harmonize conflicting rules that would otherwise exist simultaneously. What is sought is compatibility between the current Court and its former self.

Rule-of-law implications also take on a unique valence in the context of horizontal precedent. Invoking a preexisting principle in order to resolve a hot-button debate can promote the rule of law by emphasizing the primacy of general, overarching norms that transcend the ideologies and idiosyncrasies of individual justices. ${ }^{173}$ Deference to past decisions helps to combat the notion that the law has no essence or principle apart from the personalities of the justices who happen to occupy the bench at any given time. ${ }^{174} \mathrm{By}$ deferring to its precedents, a court speaks with one voice.

Beyond these context-dependent implications, the vertical and horizontal axes share certain characteristics with respect to the benefits of precedential constraint. Whether the deferring body is an inferior court or the Supreme Court, respect for the past can foster stability. ${ }^{175}$ Justice Brandeis's famous statement about the value of allowing the law to "be settled" continues to resonate. ${ }^{176}$ When adjudicative change is relatively infrequent and moderate, the disruption of expectations is held in check. ${ }^{177}$ The stability of the legal order is bolstered, providing a firmer backdrop for developing informed understandings, planning future affairs, and controlling transition costs. ${ }^{178}$ In Justice Breyer's words, it is this stability that transforms an

173. See Jeremy Waldron, Stare Decisis and the Rule of Law: A Layered Approach, 111 Mich. L. REv. 1, 3-4 (2012) (describing the relationship between precedent, generality, and the rule of law).

174. See, e.g., Benjamin N. Cardozo, The Nature of the Judicial Process 150 (1921) (noting the undesirability of a system in which a court's rulings are too dependent upon its shifting personnel).

175. See, e.g., Vasquez v. Hillery, 474 U.S. 254, 265 (1986) (describing stare decisis as "the means by which we ensure that the law will not merely change erratically, but will develop in a principled and intelligible fashion"); Fallon, supra note 14, at 66 ("For the Constitution to be implemented successfully, [its] fabric must be reasonably stable and coherent; . . . doctrine therefore has a claim to adherence, even by Justices who believe it to be less than optimal.").

176. Burnet v. Coronado Oil \& Gas Co., 285 U.S. 393, 406 (1932) (Brandeis, J., dissenting) ("Stare decisis is usually the wise policy, because in most matters it is more important that the applicable rule of law be settled than that it be settled right."), overruled on other grounds by Helvering v. Mountain Producers Corp., 303 U.S. 376 (1938).

177. See, e.g., Planned Parenthood of Se. Pa. v. Casey, 505 U.S. 833, 855 (1992) ("II]nquiry into reliance counts the cost of a rule's repudiation as it would fall on those who have relied reasonably on the rule's continued application.").

178. See generally Randy J. Kozel, Precedent and Reliance, 62 Eмову L.J. 1459 (2013). 
aggregation of judicial decisions into a workable and integrated legal "system."179

Concerns about stability and predictability are so often recited as to seem almost commonplace, but that does not diminish their importance. To the extent that precedents remain substantially in flux, it will be difficult for lawyers to dispense legal advice and plan sensibly for the future. Courts also face the grim prospect of endlessly examining previously settled points rather than focusing on newly arising complexities in litigation. These factors do not necessarily mean that the scope of precedent must be defined broadly; their ultimate relevance depends on the matters of interpretive theory and constitutional understanding that are addressed below in Section C. Still, the benefits of stability and predictability loom large over discussions of precedential effect. ${ }^{180}$

Finally, note that it would be an oversimplification to conceptualize debates over precedential constraint as a zero-sum game between earlier courts and later ones. Later courts-whether subsequent iterations of the same court in the horizontal context or courts of inferior rank in the vertical context-may sometimes prefer that precedents be defined inclusively. One explanation for this preference is the conservation of resources that occurs when a preexisting proposition is binding upon future tribunals. ${ }^{181}$ In addition, and contrary to the more common trope of "activist" judges seeking to impose their ideological preferences on the law, some judges may prefer to avoid controversy, for reasons ranging from uncertainty about their conclusions to a simple desire to elude the spotlight. ${ }^{182}$ Those judges may appreciate the fact that their most divisive decisions can plausibly be dressed in the trappings of precedent. ${ }^{183}$ While some judges may resent broad constraint, others will welcome it, at least occasionally.

\section{Potential Costs of Constraint}

In both vertical and horizontal operation, precedent creates the risk of entrenching erroneous rules. When today's court is compelled to accept yesterday's unsound decision, society incurs a loss from the perpetuation of the

179. See Stephen Breyer, Making Our Democracy Work 149 (2010) ("Stability makes the judicial system and the law itself workable. Without stability the Court's decisions seem ad hoc and unpredictable-not part of a system at all.").

180. Kozel, supra note 178 , at 1465 (arguing that one "fixture in the [Supreme] Court's discussions of stare decisis is the reliance interest of stakeholders whose lives and livelihoods are affected by judicial precedent").

181. E.g., CARDozo, supra note 174 , at 149 (justifying deference to precedent based in part on the need to conserve "the labor of judges").

182. See supra Section I.A (discussing the link between deference and judicial humility).

183. Cf. Antonin Scalia, The Rule of Law as a Law of Rules, 56 U. CHI. L. Rev. 1175, 1180 (1989) ("The chances that frail men and women will stand up to their unpleasant duty [of obstructing the popular will] are greatly increased if they can stand behind the solid shield of a firm, clear principle enunciated in earlier cases."). 
incorrect rule. Rule-of-law costs can also arise from the conscious preservation of judicial gloss that misconstrues the underlying legal authority. ${ }^{184}$ Abiding by erroneous precedents can even threaten democratic values by creating distance between judicial interpretations and "the collective judgments that our representatives have authoritatively expressed." 185

The risk of error entrenchment is particularly acute when precedents are defined inclusively. It is true that numerous propositions are likely to have received serious consideration notwithstanding the fact that they are generalized, nonessential, or peripheral. Indeed, there is reason to suspect that, in some cases, the Supreme Court's affirmative decision to "reach out" to address a counterfactual or ancillary matter will reflect significant deliberation. ${ }^{186}$ What is more, even the less considered elements of Supreme Court opinions tend to be thoroughly deliberated in absolute terms. The justices benefit from the insights of multiple inferior courts and from the efforts of first-rate attorneys, highly interested stakeholders serving as amici curiae, and capable law clerks and support staff. These institutional features might suggest that the Supreme Court's dicta are likely to be "better decision rules" than the lower courts would "independently generate" given their heavier dockets and lighter resources. ${ }^{187}$

Yet even with extensive deliberation, Supreme Court justices may do a poor job of fashioning broad rules or opining on issues that are not closely connected to the facts at hand. ${ }^{188}$ This concern is featured in the scholarship of Professor Sunstein, who often (although not invariably) ${ }^{189}$ advocates an incremental approach designed to alleviate the dangers of "a lack of information," "changing circumstances," and "moral uncertainty." 190 Professor Sunstein argues that jurists should "focus their attention only on what is

184. Randy J. Kozel, The Rule of Law and the Perils of Precedent, 111 Mich. L. Rev. First IMPRESSIONs 37, 40-41 (2013), http://www.michiganlawreview.org/assets/fi/111/Kozel.pdf.

185. Caleb Nelson, Stare Decisis and Demonstrably Erroneous Precedents, 87 VA. L. Rev. 1, 62 (2001).

186. Dorf, supra note 14 , at 2002 (suggesting that a court may be "most likely to make true pronouncements when it acts on its own initiative, rather than when it addresses issues that have been framed solely by the interested parties before it").

187. Bruhl, supra note 125 , at $480-81$.

188. See Leval, supra note 63 , at 1255 ("[C]ourts are more likely to exercise flawed, illconsidered judgment, more likely to overlook salutary cautions and contraindications, more likely to pronounce flawed rules, when uttering dicta than when deciding their cases."). Similar arguments have been made with respect to the Supreme Court's treatment of facts. See Allison Orr Larsen, Factual Precedents, 162 U. PA. L. Rev. 59, 63 (2013) (arguing that the Court's peripheral or sua sponte factual conclusions do not warrant deference because, among other reasons, the "Court is not a factfinding institution" and "[f]acts change over time").

189. SunSTEIN, supra note 168, at 59 ("If advance planning is important, or if the judges have confidence in a wide ruling or a theoretically ambitious argument, then minimalism is a mistake."). But see id. at 60 (arguing that "many of the most difficult issues in constitutional law cannot sensibly be resolved by rule").

190. Id. at 5; see also Caminker, supra note 43 , at 52. 
necessary to resolve particular disputes."191 That minimalist approach bears notable similarities to then-Judge Roberts's embrace of case-by-case, "bottom up" judging during his Supreme Court confirmation hearings. ${ }^{192}$ Both views exhibit skepticism about issuing generalized edicts rather than narrow, fact-intensive rulings. ${ }^{193}$

Just as an inclusive reading of precedent carries implications for everything from uniformity to error entrenchment, an inclusive approach to precedent can affect the crafting of Supreme Court opinions. On one hand, greater confidence that peripheral and general statements will receive deference might encourage the justices to pepper their opinions with wide-ranging propositions. An inclusive view of precedent could thus be criticized as an engine of judicial activism, affording the justices unwarranted "power to render decisions on any issues they please." 194 On the other hand, the inclusive view might be associated with higher decision costs and "more fractured" opinions at the Supreme Court. ${ }^{195}$ Enhancing the forward-looking resonance of peripheral or wide-ranging statements increases the likelihood that such statements will generate significant debate and prove difficult to articulate in a way that satisfies a majority of justices. ${ }^{196}$

Other costs of precedential constraint are context dependent. By demanding adherence to a firm set of marching orders, vertical precedents can impede lower courts' ability to create value through judicial innovation. Inferior courts are often well positioned to evaluate the strengths and weaknesses of Supreme Court decisions. They observe the operation of those decisions in full factual and legal context rather than through the narrow, antiseptic frame provided by grants of certiorari on carefully crafted questions. Inferior courts also have more occasions to grapple with Supreme Court precedents than does the Supreme Court itself, whose light docket serves to limit its interventions. ${ }^{197}$ In addition, inferior courts may, by virtue

191. Sunstein, supra note 168 , at 9 ; $c$. Leval, supra note 63 , at 1261 ("Our readiness to trust a court's rulings of law depends on the assumption that the adverse parties will each vigorously assert the best defense of its positions. ... When, however, the court asserts rules outside the scope of its judgment, that salutary adversity is often absent.").

192. See Confirmation Hearing on the Nomination of John G. Roberts, Jr. to Be Chief Justice of the United States Before the S. Comm. on the Judiciary, 109th Cong. 159 (2005).

193. Christopher J. Peters, Assessing the New Judicial Minimalism, 100 Colum. L. Rev. 1454,1520 (2000) ("Narrow judicial decisionmaking, especially in areas wrought with factual or moral uncertainty . . is defensible not as a response to the supposedly superior competence of the political branches in making predictive judgments, but simply as a means of reducing the risk of judicial error in making such judgments.").

194. Abramowicz \& Stearns, supra note 5 , at 1057 n.313.

195. See Farber, supra note 6, at 1201.

196. See Schauer, supra note 123, at 684 ("Once we recognize the extent to which the words of an opinion take on a canonical role not unlike that played by the words in a statute, the process of writing those words rather than other words becomes particularly important.").

197. See Owens \& Simon, supra note 171 , at 1224 . 
of the judges' backgrounds and experiences, bring to bear useful perspectives that a Supreme Court composed of only nine justices cannot fully replicate. A broad understanding of precedential scope limits the contributions that inferior courts might otherwise make to the rational and effective operation of the law. It is certainly true that, even "after the Supreme Court has decided a case, there will often remain some vital role for the inferior courts to play." 198 But the more broadly a precedent is construed, the smaller that role will be.

The obvious response to these concerns is that inferior courts can exhibit grumbling fidelity to precedent simply by voicing their disapproval. Established norms of opinion-writing permit judges to criticize a Supreme Court decision even as they declare themselves bound to apply it. ${ }^{199}$ In articulating their substantive disagreement with precedent, inferior judges can alert the Supreme Court to the perceived vulnerabilities of a given decision. ${ }^{200}$ That option remains available regardless of how broadly the scope of precedent is defined. ${ }^{201}$ The Supreme Court will then have the opportunity to determine whether the inferior judges' advice ought to be heeded.

Still, this solution is underwhelming as a practical matter. The Supreme Court exercises almost complete discretion over its docket. The Court is under no obligation to hear a case simply because one or more federal judges have expressed disapproval of a precedent. The odds of attracting attention would almost surely be better if an inferior court were actually to depart from a prior statement of the Supreme Court or candidly truncate a rule the Court previously announced. ${ }^{202}$ In those situations, the justices presumably would be more inclined to exercise their supervisory authority to respond to the inferior court's dissention. ${ }^{203} \mathrm{~A}$ federal judge's ability to draw

198. Steven G. Calabresi \& Gary Lawson, Equity and Hierarchy: Reflections on the Harris Execution, 102 Y ALE L.J. 255, 277 (1992).

199. Caminker, supra note 153, at 863 (discussing the use of critical concurrences).

200. E.g., Fisher v. Univ. of Tex, at Austin, 631 F.3d 213, 247 (5th Cir. 2011) (Garza, J., concurring) ("The Supreme Court has chosen this erroneous path and only the Court can rectify the error."), vacated and remanded, 133 S. Ct. 2411 (2013).

201. E.g., W. Tradition P'ship, Inc. v. Attorney Gen., 271 P.3d 1, 34 (Mont. 2011) (Nelson, J., dissenting) ("While, as a member of this Court, I am bound to follow Citizens United, I do not have to agree with the Supreme Court's decision. And, to be absolutely clear, I do not agree with it." (footnote omitted)); see J. Harvie Wilkinson III, Of Guns, Abortions, and the Unraveling Rule of Law, 95 VA. L. REv. 253, 255-56 (2009) (emphasizing the duty of inferiorcourt judges to respect the Supreme Court but adding that "esteem can likewise be manifest in the respectful expression of difference-that too is the essence of the judicial craft").

202. See Sup. CT. R. 10(c) (2010) (including among the "[c]onsiderations [g]overning [re]view on [c]ertiorari" whether "a state court or a United States court of appeals . . . has decided an important federal question in a way that conflicts with relevant decisions of this Court").

203. Caminker, supra note 153 , at 863 (noting the possibility that "outright disobedience, given its unique emotive force, is more likely to attract the Supreme Court's attention and encourage discretionary review than is the more subtle critical concurrence"). 
attention to the Supreme Court's missteps is thus impaired when she must rely on grumbling fidelity as opposed to outright opposition. ${ }^{204}$

Of course, even when inferior courts are compelled to follow a troublesome precedent, the Supreme Court can stamp out the sparks of error. Therein lies the most dramatic difference between the vertical and horizontal contexts in contributing to the costs of precedential constraint. It is always within the power of the Supreme Court to reconsider its precedents during the course of appellate review. But when the justices defer to a past mistake on grounds of stare decisis, entrenchment of error goes from theoretical possibility to concrete reality. Absent a constitutional amendment or effective legislative response, there is no supervisory authority with the ability to correct the justices' work. While the prospect of Supreme Court review serves as a safeguard against the entrenchment of flawed precedents in the lower courts, there is no such safety net when deference comes from the Supreme Court itself.

\section{Differential Approaches to Scope}

The foregoing discussion has assumed that the scope of precedent is defined identically in the vertical and horizontal contexts. That is, the parts of a Supreme Court decision that are binding upon inferior courts are the same parts that are binding upon future iterations of the Supreme Court. Further, the parts of a precedent that the Supreme Court may choose to disregard are equally dispensable from the standpoint of inferior courts.

This assumption may be relaxed. It is possible to imagine a scenario in which the Supreme Court construes its precedents quite narrowly even while demanding inclusive interpretations among the inferior courts. The explanation might be that the virtues of uniformity and the need for guidance justify an inclusive approach to vertical precedent, while the dangers of entrenching mistakes warrant a narrower view of precedent in the Supreme Court itself.

Such an arrangement would be susceptible to some of the challenges discussed above. To take just one example, a Supreme Court that adopts a narrow view of its own precedents may reduce the entrenchment of error, but it will generate countervailing costs in terms of stability and continuity. ${ }^{205}$ While differential approaches to the scope of precedent are tools for maximizing the benefits of constraint while minimizing its costs, even the most ingenious solution will involve trade-offs. Differential approaches accordingly present the same conceptual issues as uniform definitions that treat precedential scope identically across the vertical and horizontal domains.

204. Akhil Reed Amar, America's Unwritten Constitution 232 (2012) ("An inferior may tell his boss that she is wrong, but must nevertheless follow her instructions.").

205. See supra Section III.B.1. 


\section{Precedential Scope and Interpretive Foundations}

The previous Section surveyed the costs and benefits associated with competing visions of precedential scope. Translating those costs and benefits into normative conclusions requires an appeal to deeper premises that define the role of the federal courts and the proper ends of constitutional interpretation. The following subsections examine several constitutional methodologies and their respective implications for the choice between the inclusive and restrictive approaches to precedent.

\section{Common Law Constitutionalism}

Some methods of constitutional interpretation imply an inclusive scope of precedent. Prominent among them is common law constitutionalism, which seeks to promote the evolution of constitutional law toward moral and just results while recognizing the value of precedent on grounds including constraint and humility. ${ }^{206}$

Common law constitutionalism is consistent with presumptive fidelity to past judicial statements regardless of whether they are categorized as holdings or dicta. The common law approach depends on leveraging precedent as a source of meaningful constraint on judges. ${ }^{207}$ Stripping precedents to their narrow core would undermine that constraining function, as subsequent judges would possess extensive discretion to indulge their own subjective intuitions. A broad vision of precedent thus inheres in the very nature of common law constitutionalism. Truncate the scope of precedent and the theory comes undone.

The importance of construing precedents broadly is amplified because, unlike interpretive methodologies such as originalism, common law constitutionalism declines to fall back on fidelity to the Constitution's original meaning as a source of constraint. ${ }^{208}$ Without a healthy regard for precedent, judges would be left largely to their own devices. An inclusive approach to precedent helps common law constitutionalism to ensure that today's judges face genuine constraint through the pronouncements of their predecessors. By contrast, common law constitutionalism's focus on judicial humility and deference to "the collected wisdom reflected in what others have done"209 clashes with a restrictive approach to precedent that dismisses a vast amount

206. See Strauss, supra note 3, at 891-96.

207. David A. Strauss, Originalism, Precedent, and Candor, 22 Const. Comment. 299, 300 (2005) (" $[\mathrm{M}]$ any constitutional principles that are morally appealing are simply off limits, because of precedent.").

208. Indeed, common law constitutionalists have questioned whether original meaning can be an effective source of constraint. E.g., David A. Strauss, Why Conservatives Shouldn't Be Originalists, 31 Harv. J.L. \& PuB. Pol'y 969, 973 (2008) ("Judges pick and choose among precedents, often overrule precedents, and follow precedent uncertainly. But it seems to me that originalism is much more manipulable. As a practical matter, precedent closes off many options." (footnote omitted)).

209. David A. Strauss, The Common Law Genius of the Warren Court, 49 WM. \& MARY L. REV. 845, 857 (2007). 
of judicial analysis as undeserving of deference. The more coherent practice for the common law constitutionalist is to pay close attention to the analysis contained in the judicial opinions of the past, regardless of whether that analysis was general or specific, broad or narrow, holding or dictum. The aim is to take seriously what has gone before.

To be sure, common law constitutionalism entails that precedents may be overruled when they impair the sound or just implementation of constitutional law. But that issue is one of precedential strength, not scope. ${ }^{210} \mathrm{Re}-$ gardless of how powerfully a precedent is deemed to constrain, the common law-constitutionalist position is most compatible with a capacious view of precedential scope that contemplates at least some degree of deference for a wide array of judicial propositions.

It does not follow that common law constitutionalism must eschew all other safeguards against judicial overreaching. For a common law constitutionalist who supports the incremental evolution of the law, the inclusive paradigm of precedent can raise concerns by permitting judges to make sweeping changes in the course of a single opinion. Mitigating that risk requires judges to fight the urge to draw their opinions broadly even when precedent provides no obstacle to their doing so. By combining a principle of restraint in one's own pronouncements with a practice of giving serious regard to the pronouncements of one's predecessors, common law constitutionalism can facilitate gradualism in adjudicative change.

Ultimately, then, the premises of common law constitutionalism suggest the need for an inclusive paradigm of precedent in which presumptive deference attaches to general rules, rationales, and doctrinal frameworks in addition to narrow results. More generally, the example of common law constitutionalism begins to illustrate how beliefs about the nature of constitutional interpretation can support a particular vision of precedential scope.

\section{Originalism}

While common law constitutionalism is compatible with the inclusive paradigm of precedent, other interpretive methodologies imply a different vision of precedential scope.

Consider the case of originalism. The common ground for originalists is a belief that "the original meaning of each provision of the Constitution was fixed at the time of its framing and ratification."211 This focus on fixed meanings can seem to put originalism at odds with deference to judicial precedents that deviate from the enacted Constitution. And, in fact, some originalists have emphasized that tension in challenging the doctrine of stare decisis. ${ }^{212}$ Other originalists do not go so far as to disavow any adherence to

210. See supra Section I.A.

211. Lawrence B. Solum, Faith and Fidelity: Originalism and the Possibility of Constitutional Redemption, 91 Tex. L. REv. 147, 154 (2012).

212. See generally Gary Lawson, The Constitutional Case Against Precedent, 17 HARv. J.L. \& Pub. Pol'y 23 (1994); Michael Stokes Paulsen, The Intrinsically Corrupting Influence of Precedent, 22 Const. Comment. 289 (2005). 
incorrect precedents, but, in light of their fidelity to original meanings, they nevertheless limit the extent to which they recognize stare decisis as authorizing deviations from the enacted Constitution. ${ }^{213}$

One way in which originalists can manage the relationship between stare decisis and the Constitution's original meaning is by adopting a narrow view of precedential scope. By construing precedents narrowly, originalists can find some room for stare decisis while controlling the extent to which judicial gloss obstructs the implementation of the Constitution's original meaning. ${ }^{214}$ Yet this observation is too simple to capture the nuanced relationship between precedent and original meaning, for there is a great deal of conceptual disagreement even among proponents of originalism. That disagreement includes the normative justifications for adopting the originalist methodology, which in turn determine the proper role of judicial precedent.

A concrete example will be useful. Among those who have argued for the compatibility of original meaning with judicial precedent are consequentialist originalists. For consequentialists, a central reason for abiding by the Constitution's original meaning is the belief that, because the Constitution was the product of supermajoritarian agreement, it will tend to yield desirable results. ${ }^{215}$ Even so, the consequentialist position permits the displacement of original meaning with judicial precedent in certain situations. For example, courts may depart from the Constitution's original meaning in cases involving "entrenched precedents," which "are so strongly supported that they would be enacted by constitutional amendment if they were overturned by the courts." 216 In such cases, a belief in supermajoritarian wisdom is compatible with deference to precedent notwithstanding the resulting deviation from the Constitution's original meaning. ${ }^{217}$

This reasoning is easy enough to apply to substantive rules. It is plausible that rules such as "racial segregation in public schools is not allowed"218 and "paper money is valid" 219 enjoy supermajoritarian support. Doctrinal

213. See, e.g., McGinnis \& Rappaport, supra note 3, at 805 (defending an "intermediate" position on precedent); Lash, supra note 3, at 1441 ("Preserving legitimacy under popular sovereignty-based originalism . . . does not require the complete abandonment of stare decisis.").

214. It also remains possible to argue that originalist precedents should be interpreted broadly while nonoriginalist precedents should be narrowly construed, although that distinction requires its own defense.

215. McGinnis \& Rappaport, supra note 3, at 831. Other benefits noted by the authors include "the clarity, predictability, and judicial constraint" that originalism can produce and the preservation of the "important role of the constitutional amendment process" as the proper avenue for constitutional updating. Id. at 831-32.

216. Id. at 837 .

217. Id. at 837-38. Professor Amar reaches a similar conclusion through focusing on principles of popular sovereignty. See AMAR, supra note 204, at 238 ("An erroneous precedent that improperly deviates from the written Constitution may in some situations stand if the precedent is later championed not merely by the Court, but also by the people.").

218. Brown v. Bd. of Educ., 347 U.S. 483, 495 (1954).

219. Julliard v. Greenman, 110 U.S. 421 (1884); Knox v. Lee, 79 U.S. (12 Wall.) 457 $(1870)$. 
frameworks and broadly articulated rationales, by contrast, will seldom rise to that level. While consequentialist originalism is theoretically consistent with a broad definition of precedent in those rare cases where a precedent's general prescriptions or animating principles have achieved supermajoritarian acceptance, the more likely scenario would seem to be one in which substantive rules enjoy supermajoritarian support while other elements of judicial opinions do not. The effect would be to align consequentialist originalism with a restrictive paradigm of precedent in order to avoid privileging judicial pronouncements whose supermajoritarian support is wanting.

But supermajoritarian acceptance is not the only consequentialist rationale for following precedent. Consequentialists also contend that the Constitution's original meaning should yield to judicial precedent in situations where an overruling would create "enormous costs." 220 Again, this argument applies most naturally to judicial results-the example of paper money remains salient-rather than abstract or extraneous rhetoric. Still, it is possible that departing from a prior court's generalized statements or doctrinal frameworks could threaten substantial disruption.

Recall the example of McDonald $v$. City of Chicago, in which the Supreme Court discussed the selective-incorporation framework that has been applied in numerous cases involving the assertion of constitutional rights against the states. ${ }^{221}$ Revising that framework would create serious costs by undermining settled expectations. It would also increase the expenditure of judicial resources as future courts attempted to understand and apply the new regime. These implications are significant from the consequentialist perspective. Further, they illustrate the general point that, when transition costs are great, the consequentialist position can be consistent with deference to aspects of Supreme Court opinions such as doctrinal frameworks that extend well beyond their central rulings.

On balance, then, consequentialist originalism will often cohere with a restrictive understanding that limits the precedential effect of constitutional decisions to their substantive results. But given the theory's overarching concern with functional costs and benefits, consequentialist originalism may suggest a more inclusive understanding of precedential scope under limited circumstances. As with the example of common law constitutionalism, consequentialism's normative premises provide the basis for its definition of the proper precedential scope.

\section{Pragmatism}

The scope of precedent takes still another shape within pragmatic approaches to interpretation. Pragmatic judging, as described by proponents such as Justice Breyer, resolves constitutional disputes by relying "heavily on

220. McGinnis \& Rappaport, supra note 3, at 836.

221. 130 S. Ct. 3020 (2010); see also supra Section I.C.2. 
purposes and related consequences." 222 At the same time, pragmatism places a "thumb on the scale in the direction of stability" 223 for purposes of "mak[ing] the judicial system and the law itself workable." 224 While the touchstone is practical results, there is recognition that the benefits of standing by precedent can be considerable.

This focus on practical benefits should inform the definition of precedential scope. Legal stability can result from adherence to peripheral propositions as well as central ones. Likewise, stability can emerge from the preservation of sweeping principles as well as fact-intensive rulings. Pragmatic theories of interpretation accordingly must remain open to the possibility that the efficacy and soundness of the legal system is best promoted by adopting an inclusive view of precedent. Indeed, this type of thinking might explain Justice Breyer's approach in cases such as Parents Involved, in which he acknowledged the status of a past statement as dicta but described it as warranting deference because it "provides, and has widely been thought to provide, authoritative legal guidance." 225 From the pragmatic perspective, it is unconvincing to argue that a given proposition has no claim to deference based on some "rigid distinction[ ] between holdings and dicta."226 There must be a more careful inquiry into the practical effects of construing precedents broadly versus narrowly.

The role of reliance expectations reinforces the correlation of pragmatism with an inclusive approach to precedent. Stakeholders may make forward-looking decisions based not only on what the Supreme Court concludes but also on what it says along the way. Pragmatists tend to be solicitous of reliance interests, whether reliance manifests itself in terms of public expectations ${ }^{227}$ or private decisionmaking ${ }^{228}$ (or both). The pragmatic position implies that, if protecting reliance expectations can furnish practical benefits, those expectations should not be dismissed as inapposite merely because they attached to a passage that might technically be defined as dicta. $^{229}$

222. BREYer, supra note 179 , at 81 ; see also id. at 82 ("[T] he Court can and should take account of purposes and consequences, of institutional competences and relationships, of the values that underlie institutional collaboration, and of the need to assert constitutional limits.").

223. Id. at 153 .

224. Id. at 149 .

225. Parents Involved in Cmty. Sch. v. Seattle Sch. Dist. No. 1, 551 U.S. 701, 831 (2007) (Breyer, J., dissenting). Parents Involved is discussed supra in Section I.C.1.

226. Parents Involved, 551 U.S. at 831 (Breyer, J., dissenting).

227. See BREYER, supra note 179, at 152 ("[T]he public's reliance on a decision argues strongly (but, as Brown shows, not determinatively) against overruling an earlier case.").

228. See, e.g., Leegin Creative Leather Prods., Inc. v. PSKS, Inc., 551 U.S. 877, 925-26 (2007) (Breyer, J., dissenting) (adopting a broad view of the types of reliance expectations that are relevant to the stare-decisis calculus).

229. See Parents Involved, 551 U.S. at 831 (Breyer, J., dissenting) (arguing that the plurality "must explain to the courts and to the Nation why it would abandon guidance set forth many years before, guidance that countless others have built upon over time, and which the law has continuously embodied"). 
It does not follow that considerations of reliance or stability must always carry the day, for ultimately "the judge must make a pragmatic decision, weighing the harms and benefits of stability against change." 230 The point is simply that factors such as reliance and stability should not be treated as out of bounds based on a conception of precedential scope as "an exercise in mathematical logic." ${ }^{331}$ Countervailing concerns of policy and morality may justify departures from precedent even when such departures would create instability and disrupt reliance interests. But at the threshold level of defining the scope of precedent, the superficial line between holding and dicta should not foreclose a deeper inquiry into the relative benefits of retaining or jettisoning a flawed decision.

At the same time, pragmatism does not require that all dicta be infused with constraining force. Where a point was not "fully argued," received inadequate attention from the Court, or was "hedged" in the Court's opinion, it may be treated as nonbinding, ${ }^{232}$ factors such as a statement's evident depth of deliberation are linked to practical considerations such as its likelihood of error. Notwithstanding these limits, however, pragmatism implies receptiveness to an inclusive view of precedent in which presumptive deference can extend beyond an opinion's narrow holding.

\section{Conventionalism}

Another useful illustration of the relationship between interpretive methodology and the scope of precedent is the "conventionalist" mode of constitutional interpretation. ${ }^{233}$ Conventionalism seeks to effectuate "the consensus view about the meaning" of constitutional provisions "in the legal community of today." ${ }^{234}$ Part of respecting that consensus view is deferring to judicial precedent. ${ }^{235}$ Among the asserted benefits of conventionalism is the constraint of judges: "conventionalism basically shuts off the courts as an avenue for social change." ${ }^{236}$ Along with constraint

230. BREYER, supra note 179 , at 149.

231. Parents Involved, 551 U.S. at 831 (Breyer, J., dissenting).

232. Kirtsaeng v. John Wiley \& Sons, 133 S. Ct. 1351, 1368 (2013); see also supra Section III.A.

233. Thomas W. Merrill, Bork v. Burke, 19 Harv. J.L. \& Pub. Pol'y 509, 509 (1996).

234. Id. at 511.

235. See id. at 513 ("The conventionalist interpreter would be alert for, and would always exhibit a bias in favor of, the status quo-understood here to mean the existing consensus view about legal meaning in the contemporary legal community.").

236. Id. at 522; see also Thomas W. Merrill, The Conservative Case for Precedent, $31 \mathrm{HARV}$. J.L. \& PUB. PoL'y 977,981 (2008) ("A judiciary that stood firm with a strong theory of precedent would rechannel our nation back toward democratic institutions and away from using the courts to make social policy."); Thomas W. Merrill, Originalism, Stare Decisis, and the Promotion of Judicial Restraint, 22 Const. Comment. 271, 273 (2005) (urging "a strong theory of precedent on grounds of judicial restraint"). 
comes enhanced stability through a decreased incidence of disruptive transition. ${ }^{237}$

The conventionalist approach seems to imply support for the inclusive paradigm of precedent. ${ }^{238}$ The inclusive paradigm gives formal effect to a broad array of judicial assertions regarding the current state of the law. In so doing, it provides meaningful constraint on future jurists. By comparison, a more restrictive view of precedent would allow substantial leeway for courts to disregard what had previously been settled. The restrictive view also creates the potential for heightened instability by limiting the types of propositions to which future judges must defer-another result that is in tension with the conventionalist philosophy. For the conventionalist method to have its desired effect of constraining judges and promoting an incremental, Burkean approach to the law, ${ }^{239}$ it should be paired with an inclusive paradigm of precedent that sweeps widely in determining which judicial propositions are entitled to deference.

As with the example of common law constitutionalism, the conventionalist approach to precedent also has implications for the creation of precedents in the first instance. ${ }^{240}$ The inclusive view of precedent need not be license for judges to engage in wide-ranging lawmaking on the understanding that their pronouncements will carry forward with binding force. To the contrary, just as future judges must give due regard to existing precedents, today's judges must exercise restraint in crafting their own opinions if they are to embody the conventionalist ideal. An inclusive definition of precedent is thus consistent with the conventionalist model, but it must be combined with a restrained mindset on the part of the judges who create the precedents of tomorrow.

\section{Other Normative Commitments and Constitutional Understandings}

Beyond the interpretive methodologies discussed above, the relationship between precedential scope and interpretive theory can be reinforced by examining other commitments that inform the role of precedent in adjudication. These premises may arise as part of a fully articulated theory of interpretation, or they may reflect discrete arguments or assumptions. In either case, they shed additional light on the connection between normative theory and precedential scope.

Professor Dorf, for example, has defended something like an inclusive view of precedent based in part on rule-of-law considerations. He argues that, "[w]hen a court discards the reasoning of a prior opinion as merely

237. See Merrill, supra note 233, at 512-13 (defending interpretations that "provide the least disruption to settled understandings that can be discerned in the surrounding legal landscape").

238. Cf. id. at 514 (describing the "sources of conventional meaning" to include "Supreme Court precedent, read broadly").

239. See generally id. (drawing on the work of Edmund Burke in defending the conventionalist method of interpretation).

240. See supra Section III.C.1. 
dictum," it threatens to "relegate[ ] the prior decision to the position of an unjustifiable, arbitrary exercise of judicial power." ${ }^{241}$ Professor Farber has also invoked the rule of law in arguing against the practice of confining prior constitutional decisions "to their facts." 242 Even so, he cautions that respect for precedent is not the same as treating prior decisions as rigid rules. In general, the better approach is to characterize constitutional rulings as flexible "standards," making it "easier to gain and then maintain majority support for them." 243

Professor Solum has drawn on the rule of law to advance a very different position. He defends a "neoformalist conception" of precedent in which "[i]ndividual cases have holdings that are limited to their legally salient facts" and "[o]nly a line of cases can develop a rule that approximates legislation." 244 Professor Solum's theory suggests sympathy for a restrictive conception of precedent that curbs the Supreme Court's ability to articulate sweeping doctrinal frameworks that venture far beyond the case at hand.

Professor Caminker, another scholarly authority on the role of precedent, has defended inferior-court obedience on grounds including "judicial economy," "national uniformity of federal law," and the "decisionmaking prowess" of superior courts on matters of legal interpretation. ${ }^{245}$ Such a view is consistent with the inclusive paradigm of precedent, as highlighted by Professor Caminker's argument that lower-court judges should obey "well-considered dicta" from the Supreme Court.246 For some jurists and commentators, by contrast, the proper relationship between the Supreme Court and lower courts takes a different form; recall Judge Leval's view of the lower courts' "responsibility to deliberate and decide the question which needs to be decided."247

It is also important to bear in mind the role of constitutional text. By speaking in terms of a "judicial power" that extends to "Cases" and "Controversies," 248 Article III arguably suggests that deference should be withheld from judicial hypothesizing ${ }^{249}$ and perhaps even rulemaking. ${ }^{250}$ Likewise, one

241. Dorf, supra note 14, at 2029-30. Professor Dorf notes a potential exception where the subsequent court "suggests an alternative basis for the outcome of the precedent case." Id. at 2030 .

242. Farber, supra note 6 , at 1183 .

243. Id. at 1202 .

244. Solum, supra note 155 , at 191.

245. Caminker, supra note 43 , at $36-43$.

246. Id. at 73 .

247. Leval, supra note 63 , at 1250 .

248. U.S. Const. art. III, $\$ 2$.

249. See Leval, supra note 63 , at 1259 ("Given that the court's sole constitutional authority is to decide cases, what should we make of the constitutional legitimacy of lawmaking through proclamation of dicta? It is simply without justification.").

250. Bhagwat, supra note 124, at 998 (noting the argument that "the fundamental role of courts, as understood traditionally and even today, is to resolve a particular dispute and to grant a judgment, not to pronounce law"). 
might view the scope of precedent as defined in part by the distinction between "inferior Courts" and "one supreme Court," which may imply the binding force of Supreme Court decisions on lower federal courts. ${ }^{251}$ Such arguments could potentially be supplemented or complicated by foundingera understandings regarding the structure of the judicial branch. ${ }^{252}$

Finally, deference to wide-ranging judicial statements might implicate the constitutional separation of powers. Judge Leval has emphasized this point in contending that, when judges "promulgate law through utterance of dictum made to look like a holding," they "seek to exercise a lawmaking power that [they] do not rightfully possess." 253 Justice Scalia recently expressed comparable sentiments (albeit in a different context) in United States $v$. Windsor, where he asserted that the Court's "authority begins and ends with the need to adjudge the rights of an injured party who stands before us." ${ }^{254}$ This perspective suggests a concern about judges veering into the policymaking realm that is constitutionally committed to the political branches-a concern that is exacerbated by an inclusive view of precedent. ${ }^{255}$

It is these types of theoretical and constitutional arguments from which the scope of precedent is derived. Thinking of precedential scope in terms of holdings and dicta misses a great deal of conceptual nuance that resides below the surface. The question of what a precedent "stands for" cannot be determined in a vacuum. It depends on a web of normative and methodological premises that determine the proper ends of constitutional interpretation.

251. U.S. Const. art. III, $\$ 1$; see also AMAR, supra note 204, at 232 ("The big idea here is that 'inferior' courts should generally be bound by the interpretations, implementing frameworks, specific holdings, precedential implications, and remedial precepts- the doctrine-of the Supremes."); Akhil Reed Amar, The Document and the Doctrine, 114 Harv. L. REv. 26, 80 (1999) ("Article III authorizes . . doctrinal decisions to be made by 'one supreme Court,' which presides over various 'inferior' federal courts and state courts in federal question cases."); Caminker, supra note 153, at 834 ("[I]nterpreting the supreme-inferior distinction as creating a principal-agent relationship in which inferior courts implement the will of the Supreme Court responds most coherently to the Framers' concerns about decentralized access to centralized authority."). But cf. Bhagwat, supra note 124, at 985 ("[T] he term 'inferior,' as used in Article III, does not necessarily mean 'subordinate,' nor is it necessarily a constitutional endorsement of a highly hierarchical organization for the judiciary.").

252. Cf. James E. Pfander, One Supreme Court: Supremacy, Inferiority, and the Judicial Power of The United States 41 (2009) (“[T]he Framers' very conception of a unitary and hierarchical, rather than a plural and horizontal, judiciary presupposed a duty on the part of lower courts to obey their superior."); $i d$. at 38 ("[T]he Framers surely assumed that inferior federal courts would apply the decisional rules of the Supreme Court, thus empowering litigants to gain the benefit of more conventional local justice without the necessity of litigating all the way to the Supreme Court.").

253. Leval, supra note 63 , at 1250 .

254. United States v. Windsor, 133 S. Ct. 2675, 2699 (2013) (Scalia, J., dissenting).

255. See Leval, supra note 63, at 1259. 


\section{Summary: Precedential Scope and the Supreme Court's Role}

Whether they arise from normative arguments, constitutional understandings, or some combination thereof, varying conceptions of the judicial role are crucial to the scope of precedent. Under the restrictive paradigm of precedent, the Supreme Court is, first and foremost, an adjudicator. Its ability to issue pronouncements with binding effect in future disputes is limited by the facts of the case before it. Only the Court's narrow applications of law to fact-not its generalized or peripheral ruminations-will receive deference.

The inclusive paradigm reflects a different depiction of the Supreme Court, one in which the justices are lawmakers and managers. They possess the power to articulate detailed rationales and doctrinal frameworks that will carry forward with binding force. ${ }^{256}$ And their authority to issue binding declarations derives from their managerial duty to provide meaningful guidance to the federal judges who implement their legal commands. ${ }^{257}$

One might also endorse the inclusive view of precedent based on the belief that structural features of Supreme Court decisionmaking serve to neutralize the threat of overreaching. The Court is a multimember institution that is populated by justices of varying jurisprudential sympathies. ${ }^{258}$ The grander the proposition, the more difficult it is to cobble together five votes in its favor. ${ }^{259}$ To the extent that one perceives these institutional dynamics as safeguards against Supreme Court overreaching, the inclusive model may be more attractive. The same is true if one believes that the modern Court is too wary about sweeping broadly in its rulings. Doing too little can lead to the perpetuation of unsound rules, lingering uncertainty, and conflict among lower courts. ${ }^{260}$ The inclusive paradigm ensures that, at the very least, whatever the Supreme Court does say will have maximum impact.

Surveying these competing perspectives underscores the extent to which normative commitments and understandings of the judicial role will inform

256. See Bhagwat, supra note 124 , at 1000 (criticizing the "abrupt declaration of broad, forward-looking rules" and proposing "incremental rulemaking[ ] through case-by-case formulation of narrow rules necessary to resolve particular disputes").

257. See, e.g., United States v. Bloom, 149 F.3d 649, 653 (7th Cir. 1998) ("The Court can hear only a small portion of all litigated disputes; it uses considered dicta to influence others for which there is no room on the docket.").

258. BREYER, supra note 179 , at 154 ("[B]ecause life tenure for the justices means a Court membership that changes only slowly over time, it also means that different members appointed after long intervals by different presidents may well have different philosophical views."); Kozel, supra note 24 , at 1878-80.

259. See Grove, supra note 171 , at 10 ("It will often be challenging to assemble even a fivemember majority for an expansive opinion. . . These institutional constraints establish the (very real) practical boundaries of maximalism."); $c$. Frank H. Easterbrook, Ways of Criticizing the Court, 95 Harv. L. Rev. 802, 808 (1982) ("'F]ull exposition' and disagreement coincide because the more the Court tries to explain the nature and limits of its principles, the more targets for disagreement it presents.").

260. See supra Section III.B.1. 
the definition of precedential scope. ${ }^{261}$ The scope of a precedent is not something to be discovered or divined. Scope is constructed through the lens of interpretive theory. It would be incorrect to say that a precedent can stand for anything that an interpreter wishes, but it is equally mistaken to describe precedential scope as entirely independent of the interpreter's deeper theoretical commitments.

\section{The Scope of Statutory and Common Law Precedents}

While the previous Section focused on the scope of precedent in constitutional adjudication, a comparable analysis applies to statutory and common law cases.

\section{Statutory Precedents}

Within the statutory context, a restrictive approach to precedent would extend deference only to the application of a particular statute to a discrete set of facts. An inclusive approach would go further. It would permit the Supreme Court to set forth a conclusive interpretation of a disputed statutory term that would govern future cases notwithstanding their divergent facts. ${ }^{262}$ It would also empower the Court to craft binding doctrinal frameworks for guiding the interpretation of statutes, as epitomized by the two-step Chevron ${ }^{263}$ framework in the field of administrative law. ${ }^{264}$ In its most potent form, the inclusive approach may even accord deference to methodologies such as textualism and purposivism. ${ }^{265}$ Although statutory methodologies do not generally receive deference as a matter of federal practice, ${ }^{266}$ such deference arguably could promote values such as stability, predictability, and respect for prior judicial statements-values that animate the inclusive paradigm of precedent.

261. This point applies not only to the American federal system but also to precedentbased adjudication more generally. See Jan Komárek, Reasoning with Previous Decisions: Beyond the Doctrine of Precedent, 61 Ам. J. Сомp. L. 149, 158-60 (2013) (contrasting "legislative" and "case-bound" approaches to precedent and arguing that "the conception of the 'proper' judicial reasoning differs from one jurisdiction to another"); Thomas W. Merrill, Judicial Opinions as Binding Law and as Explanations for Judgments, 15 CARDozo L. Rev. 43, 78 (1993) (arguing that "whether one thinks a more conventional, careful, and precedent-bound judiciary is good or bad will depend on one's vision of the role of the courts in society").

262. See supra Section II.A (discussing indicia of deliberation as a potential limitation on the inclusive paradigm of precedent).

263. Chevron U.S.A. Inc. v. Natural Res. Def. Council, Inc., 467 U.S. 837, 842-43 (1984).

264. See supra Section I.C.2.

265. See, e.g., Gluck, supra note 97, at 1762-64.

266. See id. at 1754 ("Methodological stare decisis ... is generally absent from the jurisprudence of mainstream federal statutory interpretation ...."); cf. Nicholas Quinn Rosenkranz, Federal Rules of Statutory Interpretation, 115 HARv. L. Rev. 2085, 2144-45 (2002) (noting within the context of statutory interpretation that "the Justices do not seem to treat methodology as part of the holding of case law"). But see Gluck, supra note 97, at 1754 (suggesting that the practice may be different in some states). 
Again, the choice between these options will depend on foundational interpretive and constitutional premises. If one ascribes great importance to preserving stability and disseminating guidance, one will be favorably inclined toward the inclusive paradigm of precedent. By comparison, a more limited depiction of the judicial role will lead to skepticism of the inclusive paradigm due to its greater tendency to displace congressional commands with judicial gloss.

\section{Common Law Precedents}

Much the same is true of common law precedents. The scope of a common law precedent depends on considerations including the perceived benefits of abiding by prior decisions, the proper role of the Supreme Court in disseminating guidance for lower courts to follow, and the degree of restraint that judges ought to demonstrate in resolving the cases before them. These factors are not derived from the superficial categories of holdings and dicta. They are matters of normative valuation and competing understandings about the appropriate operation of the judiciary.

Some jurists and commentators may view the common law as a domain in which legal evolution must occur incrementally and at the margins. Such an approach would create tension with an inclusive paradigm of precedent that allowed the Supreme Court to establish, in one fell swoop, a broad framework that was binding on future jurists. But others might defend the utility of broad frameworks in converting the common law from a space of uncertainty into a source of ascertainable and stable black-letter law. For proponents of the latter position, an inclusive approach to precedent would be legitimate and desirable. And, of course, a host of intermediate positions are available, including the view that certain pockets of the common law should embody a restrictive approach to precedent while others should reflect an inclusive approach.

\section{Reforming Precedential Scope}

The Supreme Court's jurisprudence of precedent suffers due to its estrangement from interpretive theory. Judicial vacillation between the inclusive and restrictive paradigms often occurs without sufficient elaboration of the underlying premises that inform the scope of precedent. That deficiency fuels the perception of the doctrine of stare decisis as unprincipled and result oriented. ${ }^{267}$

267. See, e.g., Adrian Vermeule, Essay, Common Law Constitutionalism and the Limits of Reason, 107 Colum. L. Rev. 1482, 1529 (2007) ("[C]ommon law theorists show that judges often implement their biases precisely by distinguishing between precedents based on immaterial or irrelevant dimensions-by holding that dog owners are safe if the bite occurred on a Tuesday."). 
Addressing this problem begins with a shift toward analytical transparency, which illuminates the deeper implications of precedential deference. From there, the remaining task is leveraging that transparency in pursuit of a jurisprudential approach that is consistent across cases.

\section{A. Analytical Transparency}

The first step in reforming the treatment of precedent is straightforward. It requires the pursuit, led by the Supreme Court, of analytical transparency in the application of precedent. That means moving beyond the superficial categories of holdings and dicta-or, better yet, ignoring those categories altogether-to grapple with the deeper justifications for construing a decision broadly or narrowly.

Transparency is distinct from judicial candor. ${ }^{268}$ Analytical transparency entails not only accurately describing one's reasons for acting but also engaging with the normative premises that motivate the action. It is candid for a judge to say that her motivation in refusing to defer to a prior statement is the statement's status as dicta. In the same way, it is candid for the Supreme Court to defend its withholding of deference from prior statements that were merely "descriptive." 269 Yet those rationales fail the test of analytical transparency, for they do not explain why unnecessary or descriptive statements are unworthy of deference.

The norm of analytical transparency does not require a judge to provide a comprehensive account of which paradigm of precedent she endorses as a general matter. It demands only that she explain the application of her reasoning to the case at hand. Does she adopt a narrow reading of precedent based on concerns about error costs or beliefs about the proper judicial role as defined by Article III? Does she adopt a broad view of precedent based on the perceived virtues of stability and judicial constraint? ${ }^{270}$ Addressing questions like these is the path to an analytically transparent doctrine of precedent.

There are numerous examples of analytical transparency in the case law and commentary. ${ }^{271}$ Consider, for example, Justice Breyer's inclusive approach to precedent in Parents Involved, ${ }^{272}$ or Judge Leval's defense of a far more restrictive view. ${ }^{273}$ The goal is to convert this sporadic practice into a uniform convention. Such a convention would foreclose the dismissal of prior propositions simply because they were descriptive or uttered in dicta.

268. See, e.g., David L. Shapiro, In Defense of Judicial Candor, 100 Harv. L. Rev. 731, 734 (1987) ("A judge . . . fulfills any requirement of candor when he believes what he is saying about the force of a particular case.").

269. United States v. Stevens, 130 S. Ct. 1577, 1586 (2010).

270. See supra Section III.C.

271. For illustrative examples, see supra Section I.B.

272. See supra Section I.C.1.

273. See supra Section I.B. 
Likewise, the convention would deny deference to wide-ranging and generalized statements, such as broad rationales and doctrinal frameworks, absent some explanation of the underlying objectives being pursued. The result would be a jurisprudence that does a better job of clarifying the factors that ultimately define the scope of precedent.

\section{B. Jurisprudential Consistency}

Once transparency is established at the level of the individual case, the next step is pursuing jurisprudential consistency across cases. If the doctrine of stare decisis is to have independent force in shaping judicial behavior, it must discourage judges from making case-specific modifications based on their individual, subjective assessments.

Achieving consistency across cases is more challenging than achieving transparency in any particular case. The reason is simple: different cases can present matters in a different light, encouraging judges to alter their approaches to suit the facts at hand. Despite these challenges, the threshold pursuit of analytical transparency increases the likelihood of consistency from case to case. Transparency encourages judges to disclose their reasons for treating some past propositions as binding and others as dispensable. Once those reasons are made plain, they are available for external stakeholders to scrutinize and cite. When submerged intuitions about precedential effect are excavated and expressed as intelligible rules, their disciplining power is enhanced. ${ }^{274}$ The act of articulating premises may also make those premises clearer to the judge herself, improving the prospects of a transparent and consistent account of precedent.

Even so, the relationship between precedent and interpretive theory raises serious questions about the plausibility of achieving jurisprudential consistency. The Supreme Court has not adopted a consistent interpretive methodology. Instead, it exhibits an interpretive approach that is fundamentally pluralistic. ${ }^{275}$ Factors including text, enactment history, pragmatic evaluation of policy results, and principles of justice all have occasional roles to play, without any overarching theory to determine which considerations are appropriate in which circumstances. ${ }^{276}$ The Court's interpretive pluralism complicates its handling of precedent: If the justices cannot agree on a set of

274. Cf. Scalia, supra note 183 , at 1179 ("[W]hen, in writing for the majority of the Court, I adopt a general rule . . I not only constrain lower courts, I constrain myself as well.").

275. See, e.g., Andrew B. Coan, The Irrelevance of Writtenness in Constitutional Interpretation, 158 U. PA. L. REv. 1025, 1063 (2010) (noting the "substantially pluralist cast" of "contemporary American constitutional practice"); Gary S. Lawson, Reconceptualizing Chevron and Discretion: A Comment on Levin and Rubin, 72 Cht.-Kent L. Rev. 1377, 1383 (1997) ("There is no consensus in our legal system about the appropriate significance or weight to be given to the many considerations that plausibly can be thought relevant to statutory interpretation."); Cass R. Sunstein, Leaving Things Undecided, 110 Harv. L. Rev, 4, 13 (1996) (recognizing that "the Supreme Court has not made an official choice" among constitutional theories).

276. See Kozel, supra note 24 , at $1875-91$. 
principles to guide legal interpretation, how can they consistently apply derivative principles of precedent? Perhaps the current, undertheorized state of the law is the best we can hope for in a world of interpretive pluralism. ${ }^{277}$

In matters of precedential strength, interpretive pluralism seriously impedes the consistent treatment of prior cases. The Court has explained that the question of whether a precedent should be overruled depends on, among other factors, the importance of correcting a given judicial error. ${ }^{278}$ But the impact of error cannot be determined in the abstract. It requires consulting an interpretive methodology to determine what types of harms are legally relevant. ${ }^{279}$ For some jurists and commentators, a precedent is problematic if it creates unjust results. For others, considerations of justice are generally inapposite; precedents are problematic only insofar as they depart from the Constitution's original meaning. ${ }^{280}$ Interpretive theory is the metric for wading through these arguments and assessing the fallout from an erroneous decision. Without deliberate reference to interpretive theory, the calculus of whether to overrule a dubious precedent is necessarily incomplete.

As compared with the determination of precedential strength, the definition of precedential scope appears to have yielded greater consensus among Supreme Court justices. In practice, there appears to be substantial agreement among the sitting justices that the Court's institutional role is, at least occasionally, to issue generalized guidance that the lower courts must follow. Indeed, the prevalence of the inclusive paradigm implies as much. ${ }^{281}$ There also seems to be support for the notion that codifying statements and broad doctrinal frameworks can warrant deference, including deference from the Supreme Court itself, even when they are extended far beyond the factual contexts from where they originated. ${ }^{282}$ Thus, it may be that, despite their varying interpretive sympathies, the justices of the Supreme Court have generally coalesced around an inclusive view of precedent, albeit with some notable exceptions. ${ }^{283}$

If the justices have embraced something like an inclusive view of precedent, jurisprudential consistency becomes a possibility. Still, it is important to recognize the consequences of such a conclusion. First, the Court would

277. See Fallon, supra note 14, at 125-26 ("[V]iews about matters of background principle almost certainly dominate the interstices of doctrinal argument and guide contestable judgments. ... [T] he justification for this submersion of what is most fundamentally at stake must be that this is a second-best way of implementing the Constitution under circumstances of reasonable disagreement.").

278. See, e.g., Citizens United v. FEC, 558 U.S. 310, 378 (2010) (Roberts, C.J., concurring) ("When considering whether to reexamine a prior erroneous holding, we must balance the importance of having constitutional questions decided against the importance of having them decided right.").

279. See Kozel, supra note 24, at 1864.

280. See supra Section III.C.2.

281. See supra Section I.C.

282. See supra Section I.C.

283. See supra Section I.B. 
be foreclosed from dismissing past statements as undeserving of deference merely because they were nonessential, counterfactual, or "descriptive." 284 There might be other legitimate reasons for withholding deference, such as an evident lack of deliberation. ${ }^{285}$ But well-considered statements would be entitled to some degree of deference notwithstanding their status as dicta. Second, accepting the inclusive paradigm implies other understandings on the part of the Court, including the conclusion that Article III permits a fairly wide-ranging view of binding precedent.

Even assuming that the Court has found its way to something like an inclusive vision of precedential scope, analytical transparency would improve if the Court were to make its approach-and the reasons behind that approach-more explicit. Of course, it is possible to delay consideration of foundational motivations in the name of fostering consensus. In the meantime, the normative and interpretive implications of precedent could remain below the surface. Sooner or later, however, the deeper arguments surrounding the proper scope of precedent will need to rise to the surface if the doctrine of stare decisis is to achieve true consistency and coherence.

\section{Comparative Institutional Considerations}

This Article's topic has been the treatment of Supreme Court precedent in federal litigation. Before closing, I offer a few comments about the scope of precedent in other institutional contexts. I begin by considering adjudication in the federal appellate courts. I then turn to the scope of Supreme Court precedent as applied by the states, whose sovereignty raises important questions of federalism.

\section{A. Circuit Law}

Decisions of a federal court of appeals are binding on district courts within the relevant circuit. ${ }^{286}$ They also exert horizontal force on future appellate panels, which are required to follow circuit law. ${ }^{287}$ Generally, only an en banc court of appeals may overrule a panel decision, although some circuits have developed procedural alternatives to streamline the process. ${ }^{288}$

284. See United States v. Stevens, 130 S. Ct. 1577, 1586 (2010).

285. See supra Section II.A.

286. E.g., Caminker, supra note 153 , at 824 .

287. E.g., United States v. Collins, 415 F.3d 304, 311 (4th Cir. 2005) ("A decision of a panel of this court becomes the law of the circuit and is binding on other panels unless it is overruled by a subsequent en banc opinion of this court or a superseding contrary decision of the Supreme Court." (quoting Etheridge v. Norfolk \& W. Ry. Co., 9 F.3d 1087, 1090 (4th Cir. 1993)) (internal quotation marks omitted)).

288. See, e.g., 7TH CIR. R. 40(e) (providing a mechanism for overruling circuit law without an en banc rehearing upon approval by a majority of active judges); Outlaw v. Airtech Air Conditioning \& Heating, Inc., 412 F.3d 156, 160 n.1 (D.C. Cir. 2005) ("Because this part of our opinion rejects a prior statement of circuit precedent, it has been considered separately and approved by the full court."). 
The vertical and horizontal operation of circuit precedent bears some resemblance to the operation of Supreme Court precedent. The similarity may suggest that questions of precedential scope should be resolved the same way in both domains. But to assume such equivalence would be premature. There are meaningful grounds of distinction between circuit court precedents and Supreme Court precedents. For example, intermediate appellate courts may tend to make more interpretive errors than the Supreme Court. This is not necessarily due to any lesser competence but rather to the fact that the Supreme Court ordinarily gets to benefit from a circuit court's reasoning in reaching its own decision, while the reverse is not true. A reduced risk of error may also result from the Supreme Court's light docket, ${ }^{289}$ as well as from the substantial attention its cases receive from interested parties who provide diverse perspectives in the form of amicus curiae briefs. Because increased risks of error can dilute the net benefits of precedential constraint, there is a basis for concluding that circuit court decisions should be construed more narrowly than Supreme Court decisions in both vertical and horizontal operation.

The same conclusion might follow from the Supreme Court's unique position atop the judicial hierarchy. If one adopts a view of the Supreme Court as the federal judiciary's manager, it is appropriate for the Court to exercise broad powers to issue binding guidance, even in the form of generalized and wide-ranging statements. ${ }^{290}$ That justification does not carry the same resonance with respect to federal appellate courts, which have smaller areas of oversight and more cases through which they can explicate the law.

By contrast, considerations of uniformity, consistency, and stability that are associated with deference to Supreme Court precedent remain salient in the context of circuit precedent. What is more, adopting different principles of scope for Supreme Court and circuit precedents might prove troublesome to administer. In light of the administrative costs, there is an argument for applying a single model of precedential scope to Supreme Court decisions and circuit court decisions alike.

For present purposes, there is no need to proceed beyond these outlines. Extrapolating any further would require a comprehensive analysis of the ramifications of circuit precedent. In constructing a system of precedent, the initial step should be examining the implications of constraint at each level of the judicial hierarchy. Only upon completing that project can we determine whether the benefits of a uniform approach outweigh the costs of disregarding court-specific considerations.

\section{B. State-Court Interpretation}

The similarities between the Supreme Court and the circuit courts do not carry over to the relationship between the federal and state judiciaries. It

289. For a recent analysis of the effect of docket size on appellate adjudication, see generally Bert I. Huang, Lightened Scrutiny, 124 HaRv. L. REv. 1109 (2011).

290. See supra Section III.C.6. 
is well established that state courts are constrained by Supreme Court decisions on federal and constitutional matters. ${ }^{291}$ According to the justices, such constraint is meant to "preserve the integrity of federal law." ${ }^{292}$ But there are obvious differences between state courts and inferior federal courts. The first is their constitutional status. As Professor Caminker has explained, "though the Supremacy Clause declares that 'the Judges in every State shall be bound' by federal law, neither that Clause nor any other demands that state courts defer to a particular actor's interpretation of federal law."293

Further, even if one believes that state courts have a duty to follow Supreme Court decisions, uncertainty surrounds the process of defining a precedent's scope. The simplest response-that the scope of precedent should be the same as it is with respect to inferior federal courts-has the advantages of clarity and efficiency. That arrangement would also enhance the uniformity of law, at least assuming the continued prevalence of a relatively inclusive vision of vertical precedent within the federal judiciary. ${ }^{294}$

Still, it is far from obvious that the calculus should be identical once considerations of federalism enter the picture. In declining to review decisions that include an adequate and independent ground in state law, the Supreme Court has emphasized the importance of "[r]espect for the independence of state courts." ${ }^{295}$ The sovereignty of the states may justify a greater sphere of discretion for state court judges relative to inferior federal judges in the treatment of Supreme Court precedent. Even for those who

291. See 28 U.S.C. $\$ 1257$ (2012) (extending the Supreme Court's power of certiorari to "[f]inal judgments or decrees rendered by the highest court of a State" when there is a federal question or constitutional claim).

292. See Michigan v. Long, 463 U.S. 1032, 1041 (1983). Even so, such constraint does not represent the only plausible way to arrange the relationship between sovereign tribunals. An intriguing debate is underway in the United Kingdom, where the dynamic between the U.K. Supreme Court and the European Court of Human Rights is receiving considerable attention. One notable characterization of the relationship is that of Lord Phillips, who has contended that it is occasionally appropriate for the U.K. Supreme Court to "decline to follow" a decision of the European Court of Human Rights in order to afford the latter "the opportunity to reconsider the particular aspect of the decision that is in issue" and to foster a "valuable dialogue between" the two courts. R v. Horncastle, [2009] UKSC 14, [11] (appeal taken from Eng.); see also Erin F. Delaney, Judiciary Rising: Constitutional Change in the United Kingdom, 108 Nw. U. L. Rev. 543, 588-90 (2014) (situating Lord Phillips's statement within the broader context of relations between the two courts).

293. Caminker, supra note 153, at 837 (footnote omitted) (quoting U.S. CoNST. art. VI, cl. 2); see also Nelson Lund, Stare Decisis and Originalism: Judicial Disengagement from the Supreme Court's Errors, 19 Geo. Mason L. Rev. 1029, 1039 (2012) ("The Constitution nowhere characterizes [state courts] as 'inferior' to any federal court, or implies that they are to be integrated into a hierarchical federal establishment.").

294. See, e.g., Pfander, supra note 252, at 23 ("One way to avoid the expense and inconvenience of appellate review in every case was to create lower federal courts and give them final authority over disputes of modest size. Reliance on state courts as an alternative would make little sense if those courts were not similarly obliged to comply with the Supreme Court's decisions.... The structural and geographic logic of the Madisonian compromise suggests that state courts should face the same obligation to apply Supreme Court precedents as the lower federal courts, at least when they act in a comparable institutional setting.").

295. Long, 463 U.S. at 1040 . 
would generally defend a capacious definition of precedent, principles of federalism might suggest that, within the state judiciaries, only the narrow rulings of Supreme Court opinions should be constraining. The objective would be to minimize the degree of intrusion into state affairs while ensuring a core of uniformity in the application of federal and constitutional law. Similarly, those who defend broad constraint on the rationale that the lower federal courts should behave as the Supreme Court's faithful agents ${ }^{296}$ might conclude that such logic does not extend to the courts of the sovereign states. These arguments lend some plausibility to the claim that the inclusive view of precedent should be confined to federal adjudication, if only to stake out a province in which state courts can challenge sweeping pronouncements of the Supreme Court.

Articulating the precise bounds of state-court constraint is outside the scope of this Article, but the following point is clear enough: the unique dimensions of federal-state relations should inform the operation of Supreme Court precedents in the state courts. The scope of precedent must always be attuned to institutional context.

\section{Conclusion}

This Article has provided a descriptive and normative account of the scope of precedent in federal adjudication. Descriptively, the Article has claimed that Supreme Court precedents are often defined capaciously and inclusively in constraining future courts, although there are notable exceptions in which a more restrictive approach emerges. Normatively, the Article has contended that the classic distinction between holdings and dicta is inadequate for evaluating the treatment of precedent in contemporary federal practice. Whether precedents are defined narrowly or broadly should depend on considerations of interpretive methodology, constitutional understanding, and institutional context.

Finally, the Article has outlined proposals for reforming the jurisprudence of precedent in order to enhance its soundness. The first step is a commitment to analytical transparency, which brings the foundational drivers of precedential constraint to the forefront. The second, and more challenging, step is achieving jurisprudential consistency across cases. These proposals provide a framework for reconceptualizing the scope of precedent by moving beyond the superficial categories of holding and dicta and toward a richer, more meaningful discourse on the relationship between the courts of past, present, and future.

296. Cf. Pauline T. Kim, Beyond Principal-Agent Theories: Law and the Judicial Hierarchy, $105 \mathrm{Nw}$. U. L. Rev. 535, 563 (2011) (questioning the "common assumption that the lower federal courts are agents with a duty to act on behalf of the Supreme Court"). 